NBER WORKING PAPER SERIES

DOES SCIENCE PROMOTE WOMEN? EVIDENCE FROM ACADEMIA 1973-2001

\author{
Donna K. Ginther \\ Shulamit Kahn \\ Working Paper 12691 \\ http://www.nber.org/papers/w12691 \\ NATIONAL BUREAU OF ECONOMIC RESEARCH \\ 1050 Massachusetts Avenue \\ Cambridge, MA 02138 \\ November 2006
}

We thank $\mathrm{Al}$ and Judy Erickson for making this paper possible. We also thank the National Science Foundation for granting a site license to use the data and Kelly Kang of the NSF for providing technical documentation. Dylan Rassier and Ronnie Mukherjee provided research assistance. Ginther acknowledges financial support from NSF grant SES-0353703. Finally, we thank Anne Preston and Richard Freeman for their useful comments on an earlier draft. The use of NSF data does not imply NSF endorsement of the research, research methods, or conclusions contained in this report. Any errors are our own responsibility. The views expressed herein are those of the author(s) and do not necessarily reflect the views of the National Bureau of Economic Research.

(C) 2006 by Donna K. Ginther and Shulamit Kahn. All rights reserved. Short sections of text, not to exceed two paragraphs, may be quoted without explicit permission provided that full credit, including (c) notice, is given to the source. 
Does Science Promote Women? Evidence from Academia 1973-2001

Donna K. Ginther and Shulamit Kahn

NBER Working Paper No. 12691

November 2006

JEL No. J4,J71

\begin{abstract}
$\underline{\text { ABSTRACT }}$
Many studies have shown that women are under-represented in tenured ranks in the sciences. We evaluate whether gender differences in the likelihood of obtaining a tenure track job, promotion to tenure, and promotion to full professor explain these facts using the 1973-2001 Survey of Doctorate Recipients. We find that women are less likely to take tenure track positions in science, but the gender gap is entirely explained by fertility decisions. We find that in science overall, there is no gender difference in promotion to tenure or full professor after controlling for demographic, family, employer and productivity covariates and that in many cases, there is no gender difference in promotion to tenure or full professor even without controlling for covariates. However, family characteristics have different impacts on women's and men's promotion probabilities. Single women do better at each stage than single men, although this might be due to selection. Children make it less likely that women in science will advance up the academic job ladder beyond their early post-doctorate years, while both marriage and children increase men's likelihood of advancing.
\end{abstract}

Donna K. Ginther

Department of Economics

University of Kansas

dginther@ku.edu

Shulamit Kahn

Dept of Fin \& Econ; Sch of Mgmt

Boston University

595 Commonwealth Avenue

Boston, MA 02215

skahn@bu.edu 


\section{Does Science Promote Women? Evidence from Academia, 1973-2001}

Fewer women are present in science academe than in the workforce as a whole and particularly in the higher levels of academe - such as tenured jobs and full professorships at major research universities. This paper begins from the point when scientists receive their Ph.D.s and investigates gender differences as they move up the academic career ladder, getting tenure track jobs, being granted tenure, and being promoted to full professorships.

There is a large body of literature about women and science, particularly since 1982 when Congress instructed the National Science Foundation (NSF) to report biennially on the status of women and minorities in science. The NSF reports have consistently shown that since 1982 and through the most recent report (NSF 2004a), women continue to be less likely than their male colleagues to be full professors and more likely to be assistant professors. Congress also established its own committee, the Congressional Committee on the Advancement of Women and Minorities in Science, Engineering and Technological Developments (CAWMSET), to review the status of women in science. CAWMSET (2000) also found that women in SET (Science, Engineering and Technology) academia are less likely to be tenured (29 percent of women versus 58 percent of men among full time ranked academics at 4 year colleges) or hold full professorships (23 percent of women compared to 50 percent of men). More recently, the Government Accountability Office (GAO) reported to Congress that women scientists lag behind men in terms of salary and rank (GAO 2004). In site visits, some women report that tenure track positions at research universities create difficulty in balancing work and family. Others report that a hostile climate makes academic employment unattractive. Another recent study by Donna

Nelson and Diana Rogers (2005) found that smaller percentages of women than men who receive 
Ph.D.s proceed to become assistant professors in top 50 SET departments. These important sources represent only a few of the many studies on women in science.

Even though women are under-represented in upper echelons of academic science, one cannot conclude from the NSF, CAWMSET or Nelson reports that unfair treatment in the promotion process is the underlying cause of the gender gap in academic promotion. Two alternative possibilities include that women choose careers that do not have the rigid academic timetable or that women are less productive, particularly in terms of research, than men. Of course, research productivity itself may result from the absence of an environment and the resources that foster research, as demonstrated at MIT (Goldberg 1999).

In contrast to these negative findings, Long et.al. (2001) studies the careers of women in science from 1973-1995 and conclude that women have been successful in moving "from scarcity to visibility.” They find that the impact of marriage and children on women's careers had largely been eliminated by 1995, although men were still 4 percent more likely to receive tenure. On the other hand, Xie and Shauman (2003) find that marriage and children exacerbate gender differences in promotion in nonacademic science. In addition, they find the gender publication gap is smaller than in previous studies and declining over time, suggesting a convergence in women's and men's academic productivity.

A recent report by the NSF (NSF 2004b) is the most comprehensive study to date of the factors contributing to promotion in academic careers of scientists and engineers. This work, carried out contemporaneously to ours and also using NSF's longitudinal Survey of Doctorate Recipients (SDR), finds that controlling for human capital, personal characteristics and institutional factors, there remains a significant female disadvantage in the likelihood of being in a tenure track job, of receiving tenure and of being promoted to full. However, in most of their 
specifications, they find that these gender differences become statistically insignificant when family characteristics are allowed to affect men and women differently. Our findings are quite different qualitatively from theirs, for reasons we discuss in the conclusion. We find that in science, single women actually have an advantage over single men in obtaining tenure track jobs, in being granted tenure and in being promoted to full after controlling for covariates and that married men and women without children are quite similar at each of these stages overall. However, the presence of children prevents some women from ever achieving a tenure track job and thus stepping onto the academic career ladder.

The remainder of the paper is organized as follows: we first describe the data and methodology. We then discuss the entry into tenure-track jobs, describe and model the tenure decision and then describe and model promotion to full professor. The final section concludes.

\section{Data and Empirical Methodology}

Our analysis of promotion uses data from the 1973-2001 waves of the Survey of Doctorate Recipients (SDR). The SDR is a biennial, longitudinal survey of doctorate recipients from U.S. institutions conducted by the National Research Council. The SDR collects detailed information on doctorate recipients including demographic characteristics, educational background, employer characteristics, academic rank, government support, primary work activity, productivity, and salary. The SDR has undergone substantial changes in the sampling frame and survey content between the 1973 and 1993 waves (Mitchell, Moonesinge, and Cox 1998). Technical reports provided by the National Science Foundation have allowed us to construct a longitudinal data set with consistent variable definitions over time. 
We have selected a longitudinal extract of doctorate recipients in the sciences who received their Ph.D. between the years of 1972 and 1991 and remain in the survey 10 years after the Ph.D. Individuals are excluded if they are not observed more than once or if they skip more than three surveys.

We estimate three career milestones. First, we examine the probability of obtaining a tenure track job within five years of the Ph.D. Then we restrict the analysis to those who have ever held a tenure track job to estimate two promotion milestones, the first award of tenure and the first award of full professorship.

From the 1973 through 1991 surveys, respondents provided the exact year that they received tenure, which adds some accuracy given the biennial nature of the survey. For later surveys, tenure year is imputed as the first year a person is observed with tenure in the sample. We impute the year a person receives full professorship as the first year a person is observed as a tenured full professor in the sample. Given the biennial nature of the survey, years until tenure and years until full professor may be measured with one-year error.

Our analyses below include both time-varying and non-time varying independent variables. Non-time varying variables include gender, race, whether foreign born, field, and aspects of the person's Ph.D. institution. Time varying independent variables include marital status, children, employer characteristics, primary and secondary work activities, government support, and limited productivity measures (discussed below). These covariates are suggested by previous studies of academic promotion (Long, Allison, and McGinnis 1993, Ginther and Kahn 2004). Table 1 gives descriptive statistics about both dependent and covariate variables at different stages of academic careers of scientists. 
Research by Ginther and Hayes (1999, 2003), Ginther (2001, 2003, 2004), and Ginther and Kahn (2004) demonstrates that employment outcomes differ by academic field. Thus, promotion is analyzed for all scientific fields together and broken down into three major scientific fields - biological and life sciences, physical sciences, and engineering.

Measures of academic productivity are largely missing from the SDR data, but the SDR does ask questions about publications in the 1983, 1995, and 2001 surveys. The 1983 question refers to publications between 1980 and 1983 whereas the 1995 and 2001 questions refer to numbers of publications in the previous five years. We use these data to create rough measures of cumulative papers presented and publications per year past Ph.D. If productivity data are missing for a particular year (as they are prior to 1980), average observed productivity is used to impute total productivity - an admitted rough correction which nevertheless seems preferable to omitting the information altogether.

We evaluate gender differences in academic careers using both probit and hazard methodologies. In our probit analyses, first we estimate whether significant gender differences exist in the probability of a tenure track job within five years of the Ph.D. In this estimation, we exclude doctoral recipients who were unlikely to have sought academic jobs as evidenced by their immediately entering non-academic jobs upon or prior to receipt of their Ph.D. ${ }^{1}$ Second, for those who hold a tenure track job at some point in their careers, we estimate probit models of the probability of having tenure 11 years after Ph.D. In most scientific fields, this includes a period of one or more post-doctorates in addition to a period in tenure-track assistant professor jobs. In this analysis, time-varying covariates are evaluated 11 years after Ph.D. receipt. Third,

\footnotetext{
${ }^{1}$ Thus, we include anyone who held a post-doc, who had any academic appointment, or who had no job immediately after receiving their doctorate. When the results differ substantially by including those who begin their careers outside academia, we note this.
} 
for those who receive tenure (by 15 years past Ph.D.), probit analyses model the probability of being a full professor 15 years after Ph.D. In these latter probits, time-varying covariates are all evaluated at 15 years past Ph.D.

We also use proportional hazard models with time varying-covariates to estimate the likelihood each year of becoming tenured, given that the individual has survived untenured until that point, and to estimate the likelihood each year of being promoted to full, given that the individual has received tenure but has not yet been promoted to full. ${ }^{2}$ The hazard analysis allows time-varying covariates to change each year.

Before proceeding, we inject a word of caution about overall trends among science Ph.D.'s. We have grouped all scientists into three broad groups, life sciences, physical sciences and engineering. In this analysis, these three areas often have different characteristics. The problem is worse than usual when using averages, in that the combined science statistics on women are more likely to be picking up trends in the life sciences, where most of the women are, while the statistics on men are quite likely to pick up engineering which is heavily male. Accordingly, we point out when major facts differ across these broad areas.

\section{Stepping Onto the Academic Career Ladder}

The NSF conducts a census of doctorates granted in the U.S. in its Survey of Earned Doctorates. Based on these data, Figure 1 illustrates the continuous growth in the percentage of the Ph.D.’s granted in science going to females in all fields between 1974 and 2004. Life

\footnotetext{
${ }^{2}$ Hazard models are preferred to probit models because they account for censored observations. The proportional hazard model is given by:

$$
h_{i}(t)=\lambda_{o}(t) \exp \left\{\beta_{1} x_{i 1}+\ldots+\beta_{k} x_{i k}\right\}
$$

where the hazard of promotion $h_{i}(t)$ is a function of the baseline hazard $\lambda_{o}(t)$ and covariates, $x$ in equation (1). The covariates in equation (1) influence the scale of the hazard rate and are not a function of time. In addition, the hazard for any one individual is a fixed proportion to the hazard for any other person in the sample.
} 
Sciences started this period with less than 20 percent of Ph.D.s granted to females, but by the year 2004 nearly 50 percent were. Engineering started this period as the field with fewest female doctorates, and remained so for the entire quarter century. Nevertheless, the percent female of engineering doctorate recipients rose from just over one percent in 1974 to almost 18 percent by 2004.

Figure 2 uses weighted estimates from the SDR to show the changing percentage female in each academic rank over the quarter century. The general upward trend in the percentage female among assistant professors mirrors the trend in science Ph.D. awards from Figure 1. Also similar to doctorates granted, life sciences have the highest percentage female among assistant professors, with physical sciences at much lower levels and engineering at the very lowest. Other aspects of the time trends in assistant professorships (in Figure 2) compared to doctoral recipients (in Figure 1) differ by field. In life sciences, throughout the entire quarter century, fewer women than men proceed from Ph.D. receipt to a tenure track assistant professorship with the wedge during the last four years being especially large, averaging a difference of 6 percentage points. In fact, during these four years, the proportion female among assistant professors in life sciences has actually fallen despite the fact that given increasing time trends in doctoral receipt, we would have expected them to have risen. In contrast, in physical sciences the percent female among assistant professors has consistently kept pace with the percentage of female doctorates. In 2001, 25 percent of doctorates awarded to women and 26 percent of assistant professors were women. Even more extreme, in engineering, from the late 1980's until very recently, the percentage female among assistant professorships was greater than among doctorates. Between 1990 and 1997 an average of 11 percent of doctorates in engineering were granted to women whereas an average of 13 percent assistant professors were 
women. However, since 1997, the percent female among doctoral recipients has pulled ahead of that of assistant professors.

Among those women entering academia, fewer women than men have tenure track jobs within five years of Ph.D. receipt. Table 1 indicates that 58 percent of men held tenure track jobs within five years of the Ph.D. compared with 54 percent of women. These gender differences among the percentages female in tenure track jobs may not represent different jobs among otherwise identical men and women, but instead be picking up a large variety of factors such as field and Ph.D. quality that happen to be correlated with gender. Model 2 of Table 2 shows the gender differences once we control for covariates. (Results of the entire probit specifications are presented in Appendix Table A1). Even after controlling for age at Ph.D., cohort, race, origin, Ph.D. quality tier ${ }^{3}$ and field in Model 2, there is a significant gender difference in the likelihood of being in a tenure track job five years after Ph.D. receipt. This difference is, however, entirely due to life sciences which has a significant and large gender difference in the likelihood in being in a tenure track job that increases to 7.7 percent once all of these covariates are added. In contrast, for engineering and physical sciences, the gender difference is small and insignificant.

Marriage and fertility decisions may be affecting women's tenure track employment. To investigate this possibility, we include marital status, total number of children, an indicator for having children less than six years of age, and each of these interacted with gender (Table 2 Model 3). Some female interaction terms are statistically significant and suggest that family variables affect women and men quite differently.

\footnotetext{
${ }^{3}$ Quality tiers are based on rankings from the Carnegie Foundation for the Advancement of Teaching and of Comprehensive and Liberal Arts Institutions.
} 
With family characteristics entered as controls, the female coefficient in science as a whole, in life sciences, and in physical sciences becomes positive and statistically significant. This indicates that single, childless women are between 11 percent in life science to 21 percent in physical science more likely to get a tenure track job within 5 years of the Ph.D. than single, childless men. In engineering, there is no significant difference.

Being married increases men's probability of getting a tenure track job by a whopping 22 percent, in science as a whole and for each field separately. Women's chances are also helped somewhat by marriage, but only by 5 percent. ${ }^{4}$ As a result, in science as a whole a married man without children and a married woman without children are about equally likely to have a tenure track job five years after Ph.D..

Children create a marked divergence between men and women. For science as a whole, the presence of a pre-kindergarten aged child lowers women's likelihood of having a tenure track job by 8.1 percent. The presence of a grade school child has no effect. In contrast, for men, prekindergarten children have no effect on their likelihood of having a tenure track job while each child above six years old increases a man's probability of getting a tenure track job by 2.9 percent.

Some gender differences in the impact of marriage and children differ by scientific field. One of these is the impact of marriage on women. At one extreme, in engineering both sexes have equally large positive impacts of marriage (21-22\%). In life sciences, marriage increases women's likelihood of entering a tenure track job by a more modest 7.9\% (again compared to 22\% for men). Finally, in physical science, marriage does not affect women's chances at all.

\footnotetext{
${ }^{4}$ This calculation adds the coefficient of Married to the coefficient of Female*Married. Many other numbers later in this section similarly add several coefficients. For instance, the impact on men of one young child adds the coefficient on Total Children and the coefficient on Children $<=6$, while the impact on women adds to this sum the
} 
Disaggregating children's impact by field, young children especially hurt the tenure-track prospects of women in life sciences (by $-8.1 \%$ ) and in physical sciences by (-5.6\%). In engineering, while the point estimate is large (-9.8\%), it is significant only at the $20 \%$ level. Grade school children are negatively correlated with having a tenure track job for physical science only, where the impact is relatively small (-3.4\%).

The positive impact of marriage and children on men's prospects here recalls positive impact on wages and promotion in the labor market as a whole. There are three primary explanations for positive impacts. First, particularly with respect to marriage, it may be due to selection: "good catches" in the marriage market are correlated with "good catches" in the labor market. Second, it could be induced effort by people "responsible" for a family. Third, it could be favoritism by employers who know that the man has a family to support. The positive although smaller -- effect of marriage on women here suggests selection. The favoritism explanation seems not to apply to women, since employers are more apt to be prejudiced against women with a family than for them. We return to these explanations in the conclusions.

Gender differences in the likelihood of receiving a tenure track job have changed over time. In additional specifications (available upon request), the gender difference between comparable men and single women (Table 2, Model 3) was allowed to differ by year of Ph.D. Later cohorts of women did better relative to men than earlier cohorts. For instance, single women with 1972 Ph.D.'s in science had a 12.1 percent higher likelihood of entering tenure track jobs within five years than single men of that cohort, and this gender difference widened to 24.4 percent for those with 1991 Ph.D’s. Disaggregating, life science and physical science fields

coefficient of Female*Total Children and the coefficient of Female*Children $<=6$. We note in the text when the sum is not significant. 
actually saw even larger changes over cohorts, while engineering had no significant cohort differences between men and women.

\section{Empirical Analysis of Moving Up the Career Ladder: Promotion of Academic Scientists}

\section{A. Estimates of the Probability of Promotion to Tenure}

Returning to Figure 2, the dashed line shows the changing percentage female among associate professors, while Figure 3 shows the percentage female among all tenured faculty. In science as a whole, the monotonically increasing trend in associate professorships mirrors trends in assistant professorships 5 to 10 years earlier, and the levels are comparable. For instance, 26 percent female among associates in 1991 is the same as the percent female among assistant professors six years earlier. Within broad fields, however, trends in percent female among associate professorships are not at all smooth or monotonically increasing, with substantial drops in the percentage female in 1996 in life sciences and in 1993 in engineering, and stagnation in percentage female in physical sciences between 1989 and 1995.

The top panel of Table 3 summarizes the impact of gender on the probability of being promoted to tenure as captured by probit and hazard analysis, before we allow gender differences in the impact of family variables. The top panel of Table 4 summarizes tenure results when family-gender interactions are included. (Appendix Table A2 provides detailed parameter estimates for the probit model. Hazard estimates are available by request).

The first row of Table 3 shows the probit analysis of gender differences in the probability of tenure by 11 years from the doctorate controlling for all variables including marriage and 
children, but without interaction terms. These results show no significant gender differences in tenure; the point estimates of the impact of being female even vary in sign across fields.

Hazard analyses are able to capture the entire year-by-year pattern of the likelihood of receiving tenure and thus in the duration until tenure. A particular strength of this analysis is that it takes into account those observed to not have received tenure by the last survey. The second row of Table 3 presents the risk ratios from a proportional hazards model of promotion regressed on a dummy variable for gender. This risk ratio can be interpreted as the effect of being female rather than male on the probability of receiving tenure. A number less than one indicates that on average the likelihood of tenure receipt in any given year for females is less than of males. There is not a significant gender difference either for science as a whole or for any of the broad fields.

The third row of Table 3 (Model 1) shows the female risk ratio after accounting for differences in academic field, demographic, family and employer characteristics, primary and secondary work activity, and government grant support. The fourth row of Table 3 shows the female risk ratios that include productivity as well (Model 2). The risk ratios fall after controlling for these covariates in each field. This gender difference is not significant for science as a whole. By field, it is not significant except in the life sciences where women are 8 percent less likely to get tenure with all covariates, but only significant at the 10 percent level.

To illustrate how gender affects the likelihood of being promoted, in Figure 4 we have graphed a smoothed version of baseline survival function for men and women separately with the full set of covariates given in Model 2. Each baseline survival function is evaluated at the average characteristics of men and women respectively in the sample. The estimated survival function is then smoothed using a nonparametric kernel density estimator described in Allison 
(1995). The graphs demonstrate that for science as a whole and for each broad field, males are slightly more likely to remain untenured over the entire period after controlling for all covariates. Thus, the men's covariates lead them to have slightly lower levels of tenure, even though an identical man would have a higher level of tenure as a woman.

Once again, adding in controls for family, children and female-interactions changes the picture. Table 4 reports probit coefficients of these gender and family terms when included in addition to other covariates. ${ }^{5}$ We have done the same estimation with hazard analyses (details available on request). Those results are qualitatively similar except where noted.

As was true with entrance into tenure track jobs, single women are more likely than single men to receive tenure. For science as a whole, the difference is 5.9 percent. Disaggregating by broad field, it is significantly true with a very large difference (20.7 percent) in engineering. In the life and physical sciences, differences between single men and women are not statistically significant.

Marriage does not have as large an effect on men with regard to tenure receipt as it did for obtaining tenure track jobs. Marriage only significantly increases men’s likelihood of tenure in engineering (by 12.2\%) and in science as a whole (6.2\%). Marriage does not have a statistically significant effect on women in any field. Combining this with the direct gender effect, married (childless) women have similar likelihoods of tenure as married (childless) men in life sciences and physical sciences. In engineering, married (childless) women have a 19\% higher likelihood of tenure in engineering ceteris paribus, similar to the difference between single men and women in engineering.

\footnotetext{
${ }^{5}$ The covariates here include interaction terms with other variables found to have significant effects in some fields. None of the qualitative results on the female interactions change with or without these additional terms.
} 
Each school-aged child has a positive impact on the promotion probability of men in all fields. This is statistically significant in engineering (where the impact is 4.0 percent) and life science (with an impact of 2.8 percent). In physical sciences, the impact is not significant in the probit but is marginally significant in the more powerful hazard analysis. As was true in the previous section for entering the tenure track, the impact of younger children on men's tenure likelihood is zero in all fields. For women, pre-school children have no significant impact in any field (once again, adding together the 4 children coefficients). Grade school children have a large negative (-22.8\%) impact on women’s tenure in engineering only. This engineering result must be seen in the context of two other differences between engineering and other scientific fields. Engineering was the only field where young children did not hurt a woman's likelihood of being in a tenure track job five years after Ph.D., and engineering has the lowest incidence of post-docs (NSF 2006). Together, these three facts suggest that women with children in all three fields are more likely to drop off the tenure-track career path within several years post-Ph.D. However, in engineering, this occurs while they are assistant professors.

In these specifications, other variables were allowed to have different coefficients for men and women if the interaction term was found significant in any specifications. We find that in the life sciences (only), otherwise identical women were not as likely as men to get tenure in the universities with the highest ranking. However, in the life sciences, private universities were less likely to give tenure in general, but women were penalized less than men. For men, the likelihood of receiving tenure fell over the cohort years. For women, this effect was smaller, still negative in life sciences but marginally positive in engineering and physical sciences. 


\section{B. Estimates of the Probability of Promotion to Full Professorship}

Returning to Figure 2, among full professors in science, the percentage female has been steadily increasing over the quarter century shown but by 2001 had only achieved the level of female representation that had been achieved in assistant professorships and Ph.D. recipients in the early 1970s. Disaggregated, the same can be said for physical sciences and engineering. Life sciences here is the "success story", with the percentage female among full professorships continually rising to 20 percent by 2001, comparable to the level of assistant professorships in 1983. Trends and levels among tenured faculty in Figure 3 combine the trends in associate professors with those in full professors.

The bottom panels of Tables 3 and 4 summarize the impact of gender on promotion to full professorship. ${ }^{6}$ The probits and hazards reported here use two different beginning time points. The probits estimate the likelihood that someone who has received tenure has a full professorship 15 years after Ph.D. The hazards starts with first tenure receipt and study the likelihood of becoming a full professor and the duration of time it takes to get there.

The first row of the bottom panel of Table 3 gives the probit coefficient on promotion to full professor (with covariates.). For all sciences pooled, there is a significant gender difference. Breaking this down by broad fields allows us to see that this is entirely due to life sciences, where women have a 9 percent lower likelihood of being promoted to a full professorship. In the other two fields, differences are not significantly different from zero. ${ }^{7}$

\footnotetext{
${ }^{6}$ Appendix Table A3 provides detailed parameter estimates for the probit models. Hazard estimates are available on request.

${ }^{7}$ In analysis not shown, we estimated the probability of promotion to full professor 17 and 19 years after Ph.D. for life scientists as well. While women are 5 percent less likely to be promoted to full professor by 15 years after $\mathrm{Ph}$.D. receipt, they were 6 percent less likely by 17 years, but this difference is only significant at the 7 percent level. There was no significant difference in the probability of being promoted to full professor by 19 years after Ph.D. receipt.
} 
In the hazard analysis of Table 3, as before, the second row of the panel includes no covariates. The risk ratio from the proportional hazard analysis (without covariates) indicates highly significant gender differences in promotion to full in science as a whole. On average, the likelihood of promotion to full in any given year for females is 90 percent that of males. Disaggregating by field, physical science is the only one where women have a significantly lower likelihood of being promoted to full than men on average. In fact, in physical science the likelihood of being promoted to full professor in any given year for females is only 79 percent that of males.

Adding in a full set of controls in the last two rows of Table 3, however, moves the risk ratio in both the full sample and in physical sciences closer to one and makes them insignificant at standard levels of significance.

Figure 5 shows a smoothed version of the baseline survival function for men versus women with the full set of covariates, where each is evaluated at the average characteristics of men and women respectively in the sample. We omit engineering from this analysis because of the small numbers of women with tenure. The graphs demonstrate that for science as a whole and for each broad field, females are slightly less likely to have been promoted to full at most durations.

Details on the family terms are reported in the bottom panel of Table 4. Adding genderfamily interaction terms, we see that in both life and physical sciences, single women are much less likely to become full professors than single men by 15 years post-Ph.D (62\% and 77\% respectively). This reverses the advantage that single women had over men in the earlier career stages. In engineering, there is no significant difference between single men and women. Marriage does not have an impact on men's promotion to full. For women, a married woman in 
life science has a $6.3 \%$ lower chance of achieving full $(\mathrm{p}=.15)$ than a single woman, while in physical science a married woman is 12.0 percent more likely to have a full professorship $(\mathrm{p}=.08)$.

Having school aged children has no effect on men's promotion to full, except in engineering where each child makes promotion 6.4 percent more likely. Having school aged children has an effect on women's promotion to full only in the physical sciences, where in this case it lowers the probability of becoming full by 9.6 percent Finally, having young children has no clear effect on full professorship for either sex in any field, with one exception: women in engineering. In engineering, young children may raise the probability of a woman receiving full in engineering (31.1\%, significant at the $14 \%$ level).

A few other variables were shown to have different impacts on men and women. As with tenure, presently working in a Research I university hurt women’s chances of becoming full but not men's in life sciences and consequently in science as a whole. Similarly, for life sciences (and hence sciences as a whole), private universities significantly hurt women's chances of being promoted to full in the hazard model specifications--opposite to the gender difference found at promotion to tenure. Finally, unlike the tenure decision, both women's and men's likelihood of promotion to full worsen for later cohorts.

\section{Conclusions: Putting Gender Differences in Promotion into Perspective}

This paper has shown that within science as a whole, even without controls, there are no appreciable gender differences in the probability of receiving tenure, and only a five percent difference in the probability of promotion to full. Moreover, we can explain what differences that do exist in tenure and promotion to full professor by differences in academic field, 
demographic and employer characteristics, primary and secondary work activity, government grants, and publications. When broken down into broad fields, with controls there do seem to be some gender differences in promotion to tenure for life sciences only, on the order of approximately 8 percent. No broad fields demonstrate significant gender differences in promotion to full professor after including these covarates. The stage where there are gender differences is the entry stage, where there is a 3 percent gender difference in the likelihood of starting out in a tenure track job (within 5 years of Ph.D. receipt) even after controlling for these covariates.

These small or nonexistent gender differences mask much more substantial differences between men and women with identical kinds of family structures. In fact, single women are significantly more likely than single men to enter tenure track jobs and to be granted tenure ceteris paribus. Reversing this, single women who received tenure are much less likely to become full professors within fifteen years of Ph.D.

Marriage greatly increases the likelihood than men get tenure track jobs (by 22 percent), but has smaller and generally less significant effects on men’s promotion at either level. Marriage tends not to hurt women's likelihood of getting tenure track jobs, being granted tenure or becoming full. ${ }^{8}$ Often, it helps. It is striking that marriage does not hurt women in science. Dual career problems do not seem to deter women from getting a tenure track job, from getting tenure, or from becoming a full professor, despite the fact that more than 60 percent of women scientists are married to scientists (Rosser 2004).

The presence of children, however, does disadvantage women during the early post-Ph.D. years that coincide with the child-bearing window. In life sciences and physical sciences,

\footnotetext{
${ }^{8}$ The single exception is a $6 \%$ lower chance of achieving full in life sciences.
} 
children make it less likely for women to make it through the postdoc hurdle and get a tenure track job. In engineering, people tend to go directly from the doctorate receipt to jobs, bypassing the postdoc stage. Here, too, however, children make it less likely for women to be successful in academia during the early career years, lowering their likelihood of receiving tenure . Our results indicate that to some extent, women in science must make a choice between a family and an academic career. Opting out of academic career jobs because of children dovetails with some of Preston's (2004) results that show a major reason that women leave science is because of childcare responsibilities.

In contrast, for men the presence of grade school children (but not young children) is positively correlated with their likelihood of receiving tenure track jobs and receiving tenure. A gender difference is not surprising, given that men spend much less time than women in childcare, even in professional couples. Preston (2004) finds that those male scientists who do childcare have similar impacts on their academic careers.

Some of these gender differences in family variables are likely to be selection. The widespread labor market disadvantages of single men suggests that the most able men tend to get married and have children. It is possible that the negative impact of children on women entering academic careers is also selection. We cannot know whether the women who have children during the "formative" years of their careers would be less devoted to their careers even in the absence of children (i.e. a selection story), or are being hampered by their presence. To some extent, this is a chicken and egg problem.

The estimated gender differences that we have found among women scientists entering academic jobs post-PhD. are different from the recent NSF report (NSF 2004b) using the same data set. Where we find that single women have greater rates entering tenure track jobs and 
being promoted to tenure and full (ceteris paribus), the NSF found no gender differences for entering tenure track jobs and lower rates of women promoted to full. Where the NSF found that marriage hurt women's careers at various stages, we find that marriage in the absence of children does not hurt. While NSF found negative impacts of children all levels, we find negative effect of children at the point of entry into tenure track jobs only. What accounts for these very different results?

There are some small differences in our research that are not responsible for the large discrepancies in results. For instance, our analysis uses the most recent data available from the 2001 SDR. Also, other studies stopped their analysis in 1999 or earlier. NSF 2004a included a somewhat difference set of controls and did not include any publication controls.

However, the important explanation for differences between our results and the others is that we are looking only at the life sciences, physical sciences and engineering. In contrast, both Long et. al. (2001) and NSF define science as including social science. Indeed, there is a gender difference in academic promotion in social sciences which we have demonstrated in previous work. Ginther (2002) and Ginther and Kahn (2004) estimates the probability and duration to promotion for faculty in the social sciences and economics respectively. Ginther (2002a) finds a gender promotion gap in the social sciences that ranges between 10 to 12 percent (through 1997) with only half of the gap being explained by observable characteristics. In the field of economics, Kahn (1993) and Ginther and Kahn (2004) both find large gender promotion differences. Ginther and Kahn (2004) use data from the SDR (as well as independently collected data) through 2001 and find a 21 percent gender promotion gap in economics with less than half of the gap explained by observable characteristics. That paper also estimates an 8 percent promotion gap in social sciences excluding economics through 2001. 
Our results on promotion in sciences also differ from findings by Ginther and Hayes (1999, 2001) for faculty in the humanities. Using the 1977-1995 waves of the SDR and performing similar estimates, Ginther and Hayes find a gender promotion gap ranging between 7 to 9 percent. Some of the promotion gap in the humanities is explained by fertility and the treatment of work experience.

Taking all of this work together, women's disadvantages in promotion to tenure not explained by any covariates are largest in economics and other social sciences, are smaller in the humanities (in part explained by marriage and family characteristics), and non-existent in the physical or life sciences or in engineering once all variables are taken into account.

This is not to say that there are no gender differences at all in academic science careers once scientists enter tenure track jobs. Salaries of men and women are significantly different. Ginther (2001, 2003, 2004) show a significant gender salary gap in academic science especially at the full professor rank, after controlling for similar covariates including productivity. In 2001, male full professors in science earned 12 percent more than female full professors and onethird of this salary gap is not explained by observable characteristics (Ginther 2004). Although there is no significant difference in the likelihood of being promoted to full professor, compensation is apparently not equivalent.

There is some indication that the most prestigious schools are harsher on women than on men in the promotion process in the life sciences. We see this in both promotion to tenure and full, where working in a Research I university hurts women but helps men. Finally, in terms of promotion, our results agree with evidence from Long et. al. (2001) of improving conditions for women in science over the last quarter century. 


\section{$\underline{\text { References }}$}

Allison, Paul D. 1995. Survival Analysis Using the SAS System. Cary, NC: The SAS Institute, Inc.

Brown, Prudence, Dan Pasquini, and Susan Mitchell. 1997. "Methodological Report 1991 Survey of Doctorate Recipients.” Mimeo, National Research Council, Washington, DC.

Congressional Commission on the Advancement of Women and Minorities in Science, Engineering, and Technology (CAWMSET). 2000. "Land of Plenty.”

Goldberg, Carey. 1999. “MIT Acknowledges Bias Against Female Professors.” The New York Times. (March 23, 1999): p.1.

Ginther, Donna K. 2001. “Does Science Discriminate Against Women? Evidence From Academia 1973-1997” Federal Reserve Bank of Atlanta Working Paper 2001-02, February 2001.

Ginther, Donna K. 2002. "Gender Differences in Employment Outcomes for Academics in the Social Sciences.” Mimeo, University of Kansas.

Ginther, Donna K. 2003.. "Is MIT the Exception? Gender Pay Differentials in Academic Science.” Bulletin of Science, Technology, and Society 23:1, 21-26.

Ginther, Donna K. 2004. "Why Women Earn Less: Economic Explanations for the Gender Salary Gap in Science” AWIS Magazine (Winter 2004) 33:1, 6-10.

Ginther, Donna K. and Kathy J. Hayes. 1999. "Salary and Promotion Differentials by Gender for Faculty in the Humanities.” American Economic Review Papers and Proceedings 89(2): 397-402.

Ginther, Donna K. and Kathy J. Hayes. 2003. "Gender Differences in Salary and Promotion for Faculty in the Humanities,1977-1995.” The Journal of Human Resources, 38:1, 34-73.

Ginther, Donna K. and Shulamit Kahn. 2004. "Women in Economics: Moving Up or Falling Off the Academic Career Ladder?” Journal of Economic Perspectives (Summer 2004) 18:3, 193-214.

Government Accountability Office (GAO) 2004. “Women’s Participation in the Sciences Has Increased, but Agencies Need to Do More to Ensure Compliance with Title IX.” Washington DC: GAO. Available on-line at http://www.gao.gov/cgi-bin/getrpt?-GAO04-639.

Kahn, Shulamit. 1993. "Gender Differences in Academic Career Paths of Economists.” American Economic Review Papers and Proceedings 93: 52-56. 
--------. 1997. "Women in the Economics Profession.” Journal of Economic Perspectives 9(4): 193-205.

Levin, Sharon G. and Paula E. Stephan. 1998. "Gender Differences in the Rewards to Publishing in Academe: Science in the 1970s.” Sex Roles 38(11/12): 1049-1064.

Long, J. Scott, Paul D.Allison and Robert McGinnis. 1993. "Rank Advancement in Academic Careers: Sex Differences and the Effects of Productivity.” American Sociological Review 58(5): 703-722.

Long, J. Scott (ed.) 2001. From Scarcity to Visibility. Washington, DC: National Academy Press.

Massachusetts Institute of Technology Faculty Newsletter. 1999. March, 1999: 21(4) available on-line at http://web.mit.edu/fnl/women/women.html.

Mitchell, Susan B., Ramal Moonesinghe and Brenda G. Cox. 1998. "Using the Survey of Doctorate Recipients in Time-Series Analyses: 1989-1997.” Mimeo, National Science Foundation, Washington, DC.

National Science Foundation (NSF). 2004a. Women, Minorities, and Persons with Disabilities in Sciences and Engineering: 2004. NSF 00-327. Arlington, VA.

National Science Foundation (NSF). 2004b. Gender Differences in the Careers of Academic Scientists and Engineers, NSF 04-323, Project Officer, Alan I. Rapoport (Arlington, VA, 2004).

National Science Foundation (NSF), National Science Board (2006). Science and Engineering Indicators (2006). http://www.nsf.gov/statistics/seind06/2006.

Nelson, Donna J. and Diana C. Rogers. (2005). "A National Analysis of Diversity in Science and Engineering Faculties at Research Universities.” " Norman, OK. January, 2005. Available on-line at http://cheminfo.chem.ou.edu/ djn/diversity/briefings/Diversity\% 20Report\% 20Final.pdf.

Preston, Anne E. 1994. "Why Have All the Women Gone? A Study of Exit from the Science and Engineering Professions.” American Economic Review 84(5): 1446-1462.

Preston, Anne E. Leaving Science: Occupational Exit from Scientific Careers. Russell Sage Foundation: New York, 2004.

Rosser, S. V. (2004). The Science Glass Ceiling New York: Routledge.

Xie, Yu and Kimberlee A. Shauman. Women in Science: Career Processes and Outcomes. Cambridge MA: Harvard University Press, 2003. 
Table 1: Gender Differences in Mean Characteristics

\begin{tabular}{|c|c|c|c|c|c|c|}
\hline \multirow[b]{2}{*}{ Variables: } & \multicolumn{2}{|c|}{ All Doctorates $^{a}$} & \multicolumn{2}{|c|}{ Tenure-Track $^{\mathrm{b}}$} & \multicolumn{2}{|c|}{${\underline{\text { Tenured }^{c}}}^{\mathrm{C}}$} \\
\hline & Female & Male & Female & Male & Female & Male \\
\hline Tenure Track within 5 Years of Ph.D. & 0.544 & 0.582 & & & & \\
\hline Promotion to Tenure within 11 years of Ph.D. & & & 0.516 & 0.532 & & \\
\hline Promotion to Full within 15 years of Ph.D. & & & & & 0.257 & 0.316 \\
\hline Age at Ph.D. & 31.942 & 30.674 & 31.998 & 30.503 & 31.763 & 30.152 \\
\hline African American & 0.051 & 0.042 & 0.047 & 0.048 & 0.044 & 0.047 \\
\hline Native American & 0.004 & 0.004 & 0.005 & 0.005 & 0.002 & 0.004 \\
\hline Asian & 0.122 & 0.130 & 0.089 & 0.105 & 0.076 & 0.084 \\
\hline Other Race & 0.002 & 0.002 & 0.003 & 0.002 & 0.001 & 0.001 \\
\hline Foreign Born & 0.168 & 0.181 & 0.150 & 0.157 & 0.130 & 0.120 \\
\hline Year of Ph.D. & 79.672 & 80.701 & 79.265 & 80.254 & 77.263 & 78.247 \\
\hline Ph.D. from Research I & 0.732 & 0.766 & 0.739 & 0.775 & 0.740 & 0.779 \\
\hline Ph.D. from Research II & 0.108 & 0.114 & 0.102 & 0.113 & 0.101 & 0.113 \\
\hline Ph.D. from Doctorate I & 0.077 & 0.039 & 0.082 & 0.039 & 0.082 & 0.036 \\
\hline Ph.D. from Doctorate II & 0.036 & 0.029 & 0.035 & 0.027 & 0.035 & 0.031 \\
\hline Married & 0.672 & 0.804 & 0.648 & 0.846 & 0.645 & 0.849 \\
\hline Total Children & 0.756 & 1.163 & 0.752 & 1.361 & 0.767 & 1.399 \\
\hline Children $<6$ & 0.320 & 0.470 & 0.261 & 0.378 & 0.169 & 0.246 \\
\hline Cumulative Employers & & & 1.718 & 1.686 & 2.058 & 1.961 \\
\hline Private University & & & 0.274 & 0.230 & 0.272 & 0.222 \\
\hline Research I & & & 0.267 & 0.306 & 0.275 & 0.310 \\
\hline Liberal Arts I & & & 0.200 & 0.166 & 0.201 & 0.176 \\
\hline Medical School & & & 0.216 & 0.221 & 0.214 & 0.215 \\
\hline Primary Work Research & & & 0.352 & 0.456 & 0.331 & 0.427 \\
\hline Primary Work Teach & & & 0.456 & 0.377 & 0.440 & 0.372 \\
\hline Primary Work Manage & & & 0.103 & 0.079 & 0.124 & 0.108 \\
\hline Secondary Work Research & & & 0.360 & 0.397 & 0.378 & 0.406 \\
\hline Secondary Work Teach & & & 0.246 & 0.280 & 0.256 & 0.270 \\
\hline Secondary Work Manage & & & 0.127 & 0.119 & 0.145 & 0.157 \\
\hline Secondary Work Other & & & 0.135 & 0.103 & 0.106 & 0.093 \\
\hline Government Support, Current Yr & & & 0.454 & 0.534 & 0.481 & 0.540 \\
\hline Cumulative Yrs of Gvt. Support & & & 1.987 & 2.373 & 2.902 & 3.455 \\
\hline Cumulative Papers & & & 5.587 & 8.707 & 7.006 & 10.728 \\
\hline Cumulative Publications & & & 6.839 & 9.451 & 9.131 & 12.291 \\
\hline Computer Science / Mathematics & 0.126 & 0.110 & 0.159 & 0.142 & 0.149 & 0.147 \\
\hline Biology and Life Sciences & 0.566 & 0.431 & 0.559 & 0.414 & 0.588 & 0.440 \\
\hline Chemistry & 0.118 & 0.083 & 0.101 & 0.072 & 0.108 & 0.076 \\
\hline Earth Science & 0.038 & 0.060 & 0.037 & 0.064 & 0.032 & 0.067 \\
\hline Physics & 0.052 & 0.094 & 0.047 & 0.074 & 0.048 & 0.074 \\
\hline Engineering & 0.051 & 0.162 & 0.056 & 0.164 & 0.036 & 0.123 \\
\hline Observations & 4604 & 8141 & 2218 & 4406 & 1238 & 2721 \\
\hline
\end{tabular}

Notes: Numbers in Bold—male and female values significantly different at $1 \%$ level; Italics—statistically different at 5\% level. Tests are two-sided. ${ }^{\text {a }}$ Excluding doctoral recipients who were unlikely to have sought academic jobs as evidenced by their immediately entering non-academic jobs upon or prior to receipt of their Ph.D. ${ }^{\mathrm{b}}$ Timevarying variables evaluated 11 years from Ph.D. ${ }^{\mathrm{c}}$ Time-varying variables evaluated 15 years from Ph.D. 
Table 2: Probability of Having Tenure Track Appointment within 5 Years of Ph.D. by Scientific Field 1973-2001 Survey of Doctorate Recipients

\begin{tabular}{|c|c|c|c|c|c|c|c|c|c|c|c|c|}
\hline & \multicolumn{3}{|c|}{ Science } & \multicolumn{3}{|c|}{ Life Science } & \multicolumn{3}{|c|}{ Physical Science } & \multicolumn{3}{|c|}{ Engineering } \\
\hline & Model 1 & Model 2 & Model 3 & Model 1 & Model 2 & Model 3 & Model 1 & Model 2 & Model 3 & Model 1 & Model 2 & Model 3 \\
\hline \multirow[t]{2}{*}{ Female } & -0.038 & -0.033 & $\quad 0.156$ & -0.041 & -0.077 & 0.108 & -0.002 & -0.015 & 0.206 & 0.000 & 0.013 & $\begin{array}{ll}3 & 0.072\end{array}$ \\
\hline & $(0.009)$ & $(0.010)$ & $(0.018)$ & $(0.012)$ & $(0.013)$ & $(0.025)$ & $(0.016)$ & $(0.017)$ & $(0.029)$ & $(0.033)$ & $(0.035)$ & $(0.064)$ \\
\hline \multirow[t]{2}{*}{ Married } & & & 0.218 & & & 0.220 & & & 0.222 & & & 0.221 \\
\hline & & & $(0.016)$ & & & $(0.023)$ & & & $(0.026)$ & & & $(0.045)$ \\
\hline \multirow[t]{2}{*}{ Total Children } & & & 0.029 & & & 0.036 & & & $\underline{0.021}$ & & & $\underline{0.025}$ \\
\hline & & & $(0.007)$ & & & $(0.010)$ & & & $(0.012)$ & & & $(0.014)$ \\
\hline \multirow[t]{2}{*}{ Children $<6=1$} & & & -0.022 & & & -0.026 & & & -0.001 & & & $\underline{-0.069}$ \\
\hline & & & $(0.016)$ & & & $(0.023)$ & & & $(0.029)$ & & & $(0.037)$ \\
\hline \multirow[t]{2}{*}{ Female * Married } & & & -0.171 & & & -0.149 & & & -0.236 & & & 0.009 \\
\hline & & & $(0.024)$ & & & $(0.033)$ & & & $(0.041)$ & & & $(0.092)$ \\
\hline \multirow[t]{2}{*}{ Female * Total Children } & & & -0.029 & & & -0.022 & & & -0.055 & & & -0.053 \\
\hline & & & $(0.013)$ & & & $(0.017)$ & & & $(0.022)$ & & & $(0.045)$ \\
\hline \multirow[t]{2}{*}{ Female * Young Children } & & & -0.059 & & & $\underline{-0.068}$ & & & -0.021 & & & 0.000 \\
\hline & & & $(0.028)$ & & & $(0.038)$ & & & $(0.050)$ & & & $(0.100)$ \\
\hline Demographics & No & Yes & Yes & No & Yes & Yes & No & Yes & Yes & No & Yes & Yes \\
\hline Degree Characteristics & No & Yes & Yes & No & Yes & Yes & No & Yes & Yes & No & Yes & Yes \\
\hline Fields & No & Yes & Yes & No & Yes & Yes & No & Yes & Yes & No & Yes & Yes \\
\hline
\end{tabular}

Notes: Coefficients report change in probability. Standard Errors in Parentheses. Bold Significant at 1\%; Bold Italics Significant at 5\%. Underline Significant at 10\%. 
Table 3: Gender Differences in the Probability and Hazard of Promotion 1973-2001 Survey of Doctorate Recipients

Full Sample Life Science Physical Science Engineering

\section{Promotion To Tenure}

$\begin{array}{ccccc}\text { Female Probit Coefficient } & 0.00 & -0.03 & 0.01 & 0.02 \\ \text { Promoted } 11 \text { Years Past Ph.D. } & (0.88) & (0.19) & (0.73) & (0.75)\end{array}$

Risk Ratio Estimate:

$\begin{array}{rcccc}\text { Female Risk Ratio } & 0.97 & 1.02 & 1.00 & 1.06 \\ \text { (No Covariates) } & (0.33) & (0.60) & (0.96) & (0.56)\end{array}$

$\begin{array}{lllll}\text { Model } 1 \text { Female Risk Ratio } & 0.95 & \mathbf{0 . 8 9} & 0.93 & 1.00\end{array}$

$\begin{array}{lllll}\text { (Covariates ex. Productivity) } \quad(0.14) \quad(0.02) & (0.22)\end{array}$

$\begin{array}{lllll}\text { Model } 2 \text { Female Risk Ratio } & 0.97 & \underline{0.92} & 0.94 & 1.03\end{array}$

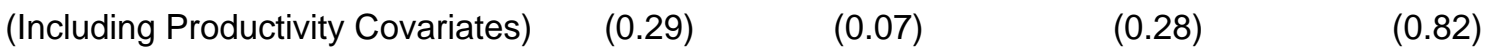

\section{Promotion To Full}

$\begin{array}{ccccc}\text { Female Probit Coefficient } & -0.05 & -0.09 & -0.02 & 0.09 \\ \text { Promoted 15 Years Past Ph.D. } & (0.02) & (0.00) & (0.51) & (0.37)\end{array}$

Risk Ratio Estimate:

Female Risk Ratio

$\begin{array}{cccc}0.90 & 0.96 & \mathbf{0 . 7 9} & 0.95 \\ (0.01) & (0.48) & (0.00) & (0.74)\end{array}$

(No Covariates) (0.01)

$(0.48)$

(0.74)

Model 1 Female Risk Ratio

$0.95 \quad 0.93$

(0.37)

0.87

1.09

(Covariates ex. Productivity)

(0.34)

(0.11)

(0.89)

Model 2 Female Risk Ratio

$0.97 \quad 0.96$

0.89

1.04

(Including Productivity Covariates) (0.54)

(0.61)

(0.19)

(0.82)

Notes: P-values in parentheses. Probit coefficient reports change in probability. Hazard coefficients are risk ratios - estimate the impact of female on the likelihood of promotion in each period. Bold Significant at 1\%; Bold Italics Significant at 5\%; Underline Significant at 10\%. 
Table 4: Marriage and Children in Probit Analysis of Tenure and Promotion to Full Professor 1973-2001 Survey of Doctorate Recipients

\begin{tabular}{|c|c|c|c|c|}
\hline & Full Sample & Life Science & Physical Science & Engineering \\
\hline \multicolumn{5}{|c|}{ Promotion to Tenure (11 years past Ph.D.) } \\
\hline \multirow[t]{2}{*}{ Female } & $\underline{0.059}$ & 0.004 & 0.024 & $\underline{0.207}$ \\
\hline & $(0.035)$ & $(0.050)$ & $(0.060)$ & $(0.086)$ \\
\hline \multirow[t]{2}{*}{ Married } & 0.062 & 0.055 & 0.058 & $\underline{0.122}$ \\
\hline & $(0.029)$ & $(0.042)$ & $(0.046)$ & $\overline{(0.073)}$ \\
\hline \multirow[t]{2}{*}{ Total Children } & 0.026 & 0.028 & 0.016 & $\underline{0.040}$ \\
\hline & $(0.010)$ & $(0.014)$ & $(0.017)$ & $\overline{(0.021)}$ \\
\hline \multirow[t]{2}{*}{ Children $<=6$} & -0.028 & -0.030 & -0.016 & -0.049 \\
\hline & $(0.023)$ & $(0.032)$ & $(0.041)$ & $(0.052)$ \\
\hline \multirow[t]{2}{*}{ Female * Married } & -0.022 & -0.031 & 0.031 & 0.012 \\
\hline & $(0.042)$ & $(0.058)$ & $(0.070)$ & $(0.152)$ \\
\hline \multirow[t]{2}{*}{ Female * Total Children } & -0.049 & -0.017 & -0.048 & -0.266 \\
\hline & $(0.020$ & $(0.026)$ & $(0.037)$ & $(0.065)$ \\
\hline \multirow[t]{2}{*}{ Female * Children $<=6$} & 0.010 & -0.028 & 0.037 & $\underline{0.175}$ \\
\hline & $(0.045)$ & $(0.061)$ & $(0.080)$ & $\overline{(0.081)}$ \\
\hline \multicolumn{5}{|c|}{ Promotion to Full (15 years past Ph.D.) } \\
\hline \multirow[t]{2}{*}{ Female } & -0.647 & $\underline{-0.620}$ & -0.771 & 0.507 \\
\hline & $(0.130)$ & $(0.216)$ & $(0.137)$ & $(0.568)$ \\
\hline \multirow[t]{2}{*}{ Married } & 0.048 & 0.070 & 0.051 & -0.026 \\
\hline & $(0.032)$ & $(0.045)$ & $(0.052)$ & $(0.103)$ \\
\hline \multirow[t]{2}{*}{ Total Children } & 0.013 & 0.009 & -0.001 & $\underline{0.064}$ \\
\hline & $(0.011)$ & $(0.015)$ & $(0.018)$ & $\overline{(0.033)}$ \\
\hline \multirow[t]{2}{*}{ Children $<=6$} & $\underline{-0.049}$ & -0.036 & -0.045 & -0.121 \\
\hline & $(0.027)$ & $(0.038)$ & $(0.045)$ & $(0.088)$ \\
\hline \multirow[t]{2}{*}{ Female * Married } & -0.073 & -0.133 & 0.069 & -0.134 \\
\hline & $(0.048)$ & $(0.060)$ & $(0.088)$ & $(0.372)$ \\
\hline \multirow[t]{2}{*}{ Female * Total Children } & -0.037 & -0.001 & -0.095 & -0.065 \\
\hline & $(0.023)$ & $(0.032)$ & $(0.040)$ & $(0.119)$ \\
\hline \multirow[t]{2}{*}{ Female * Children $<=6$} & $\underline{0.102}$ & -0.001 & 0.223 & $\underline{0.433}$ \\
\hline & $(\overline{0.063)}$ & $(0.082)$ & $(0.104)$ & $(\overline{0.092)}$ \\
\hline
\end{tabular}

Notes: Coefficients report change in probability. Standard Errors in parentheses. Bold Significant at 1\%; Bold Italics Significant at 5\%; Underline Significant at 10\%. All equations include additional controls for demographics, degree characteristics and fields. 
Figure 1: Percentage of Doctorates Granted to Females, 1974-2004 Survey of Earned Doctorates

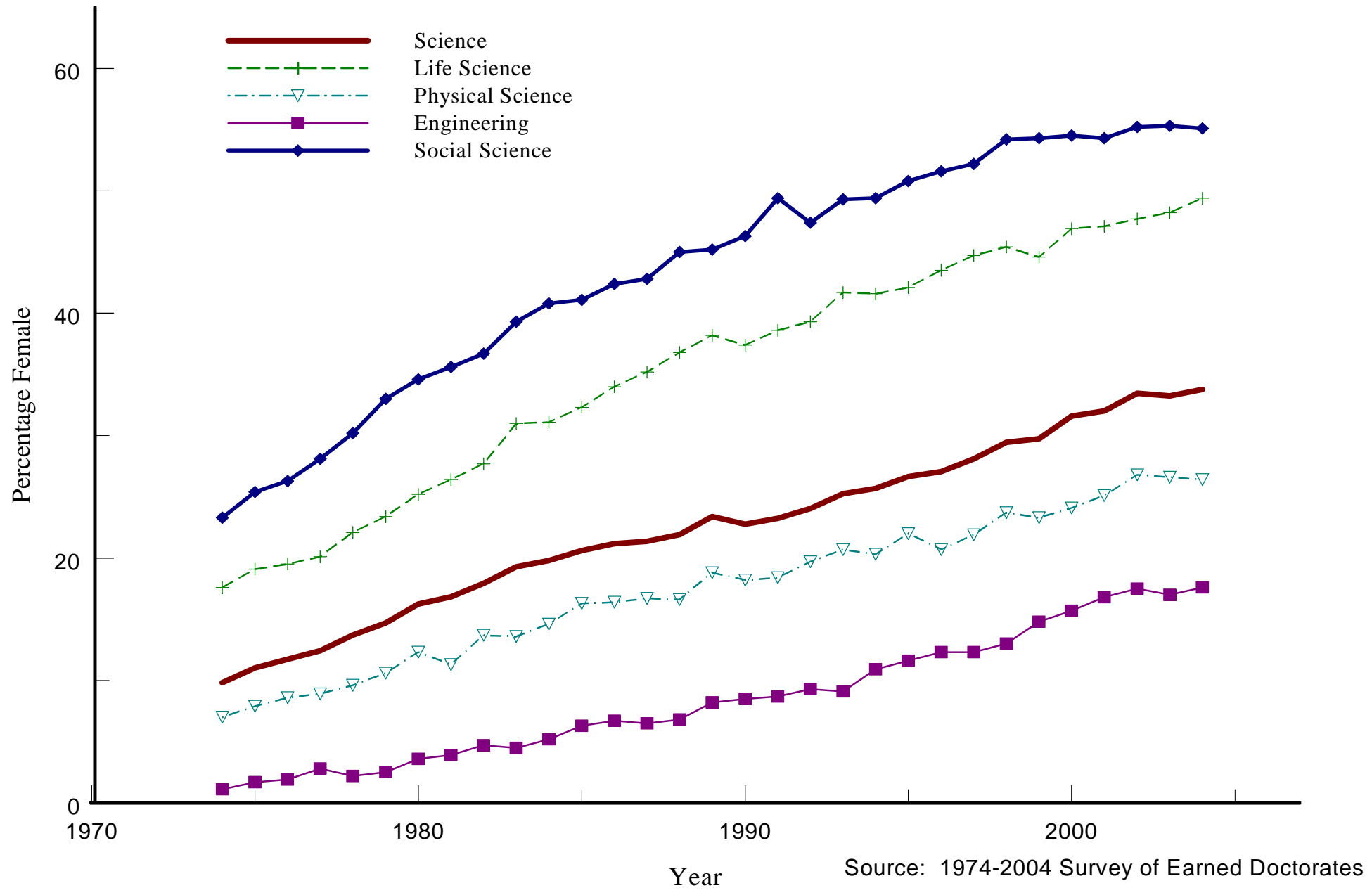


Figure 2: Percentage Female by Academic Rank, Science Disciplines
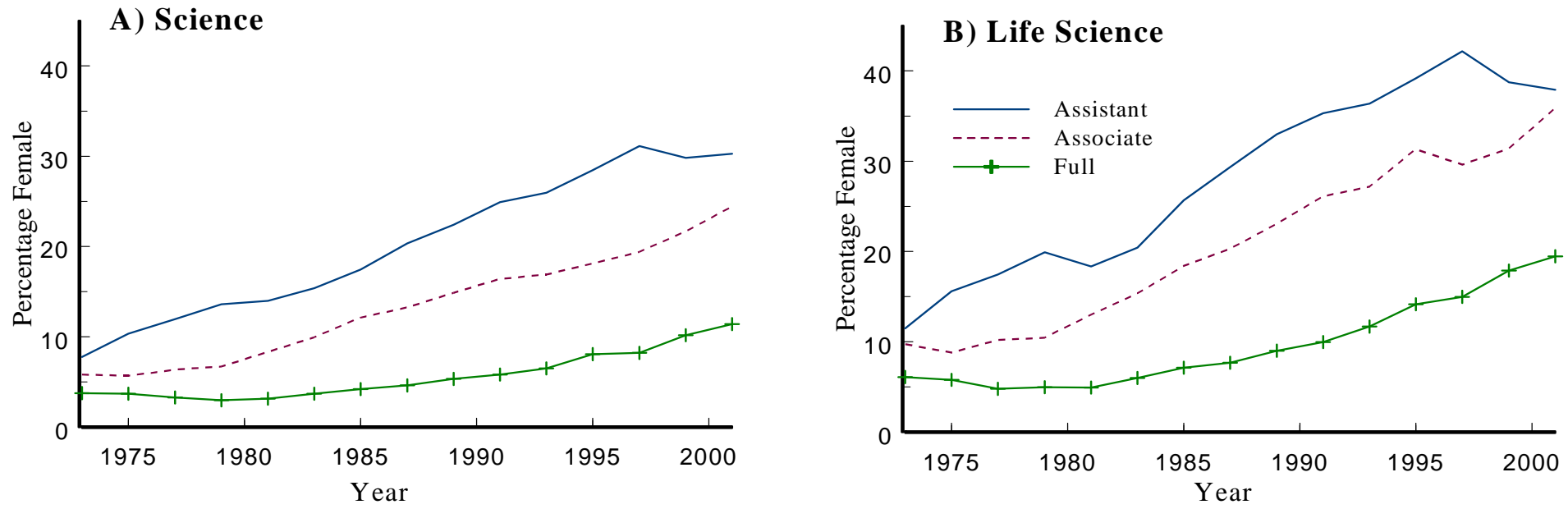

C) Physical Science

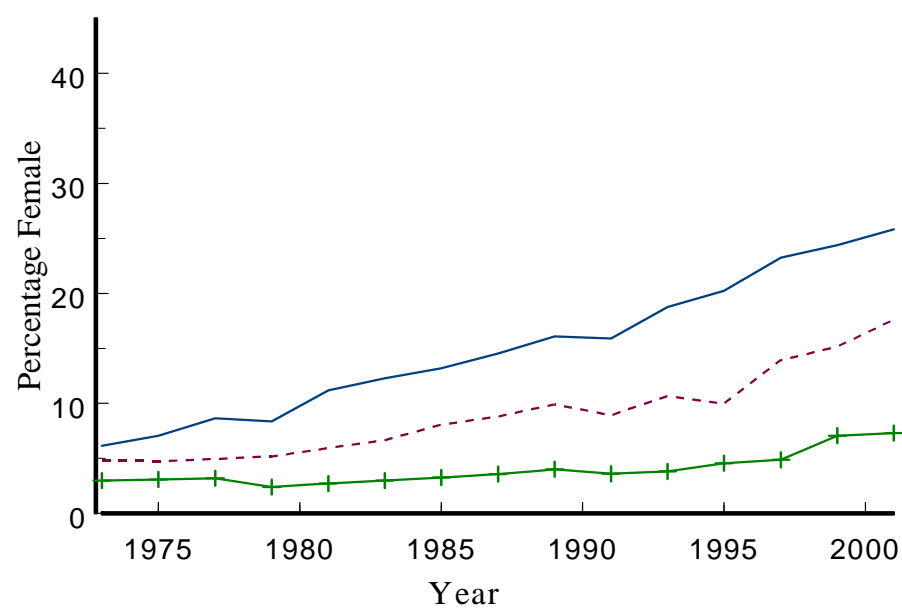

D) Engineering

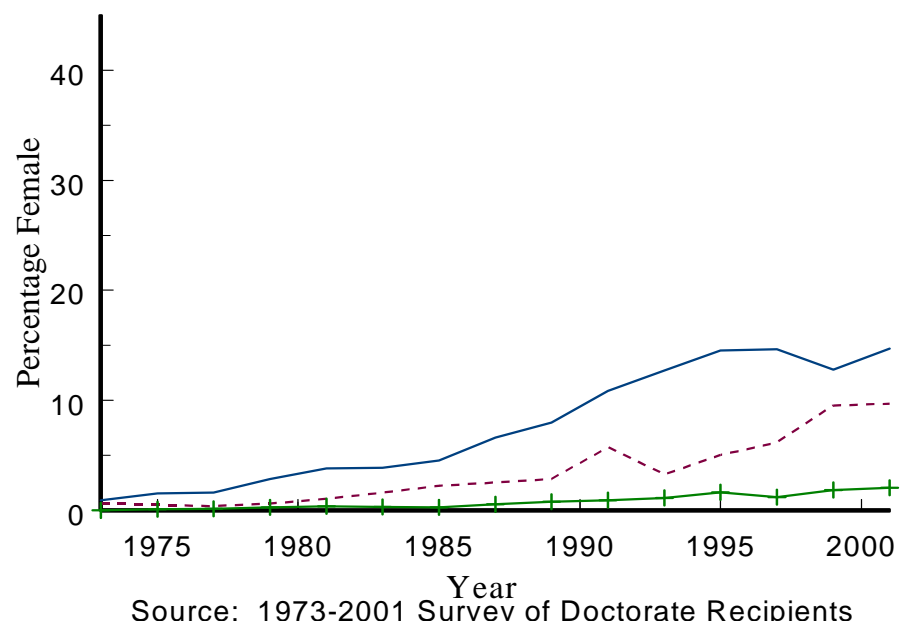


Figure 3: Percentage of Tenured Faculty who are Female, by Discipline

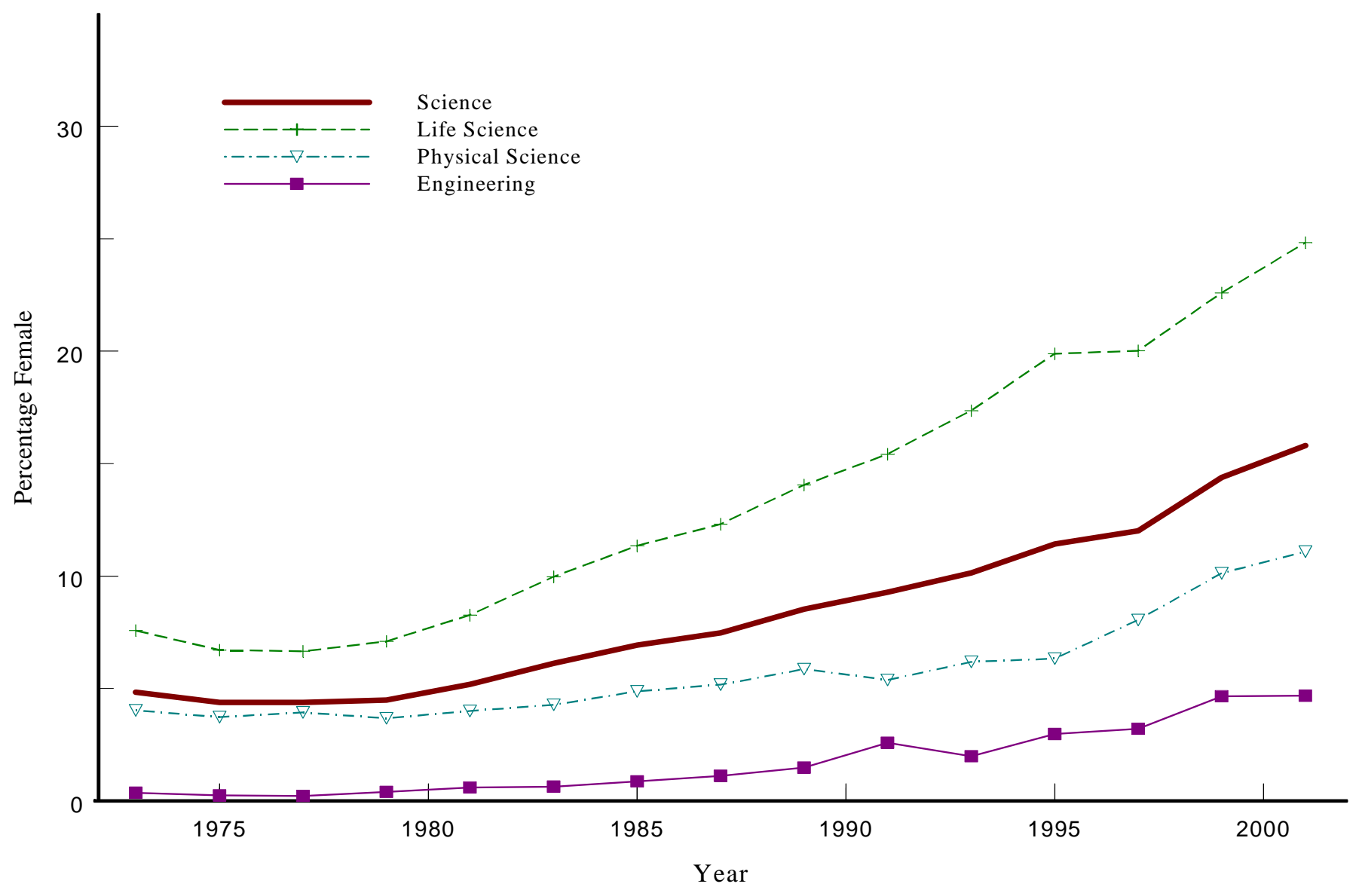

Source: 1973-2001 Survey of Doctorate Recipients 
Figure 4: Predicted Survival Without Tenure Functions, by Gender and Discipline

A. Science

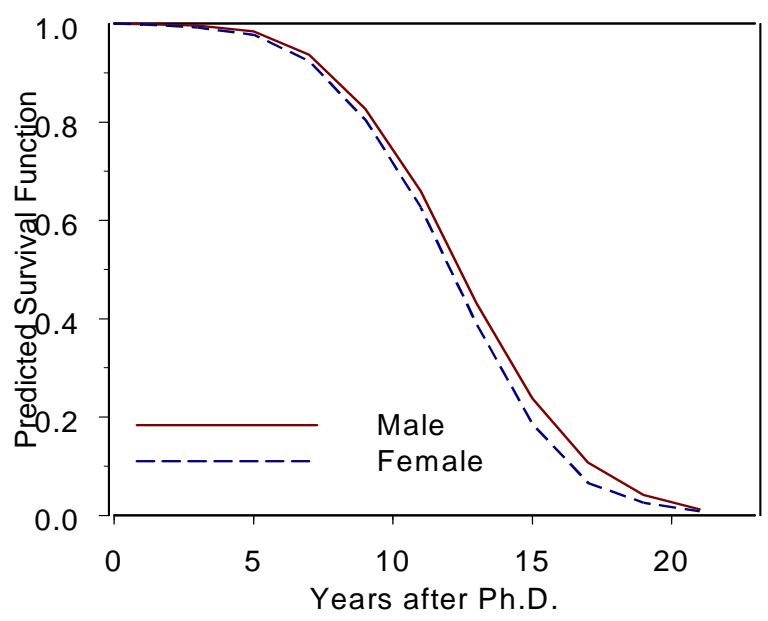

C. Physical Science

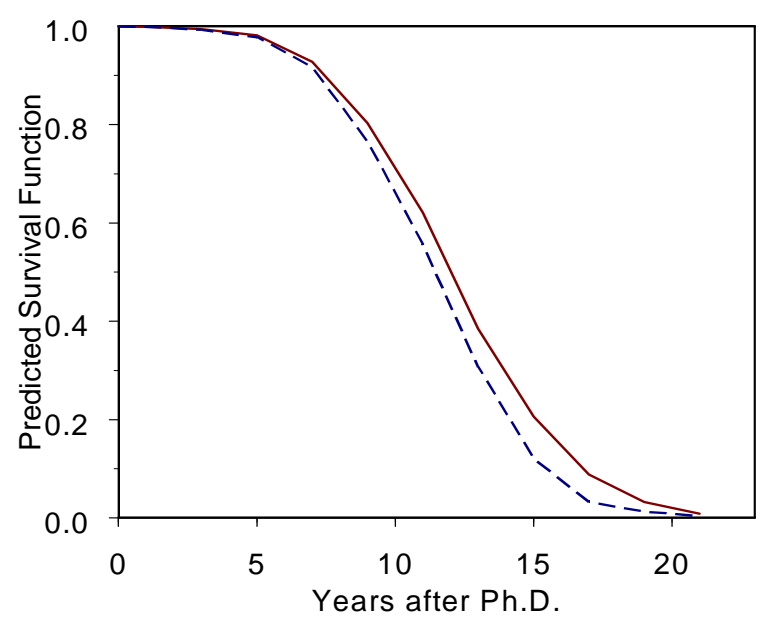

B. Life Science

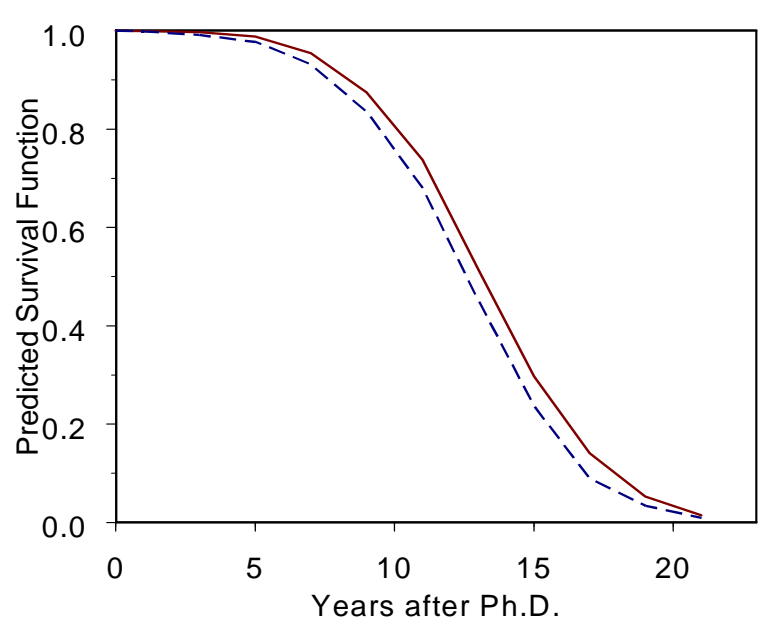

D. Engineering

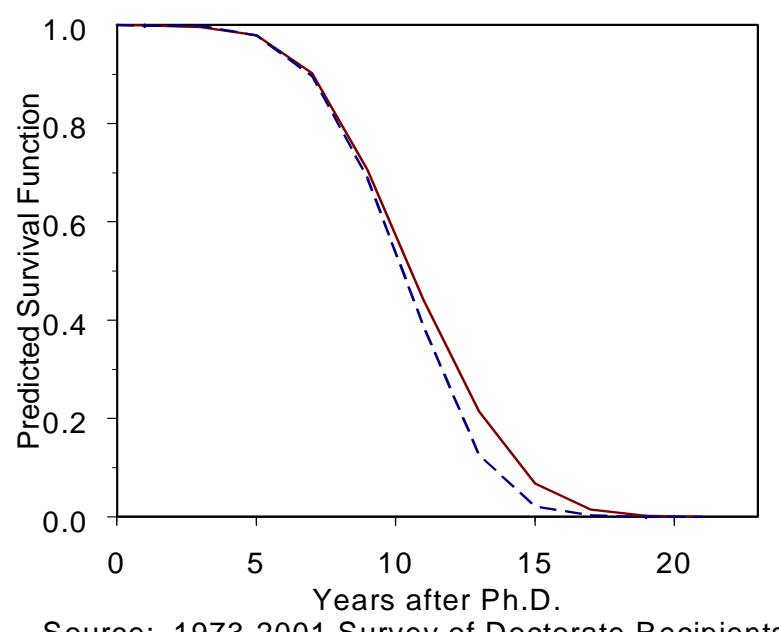

Source: 1973-2001 Survey of Doctorate Recipients 
Figure 5: Predicted Survival Without Full Professor Functions, by Gender and Discipline

A. Science

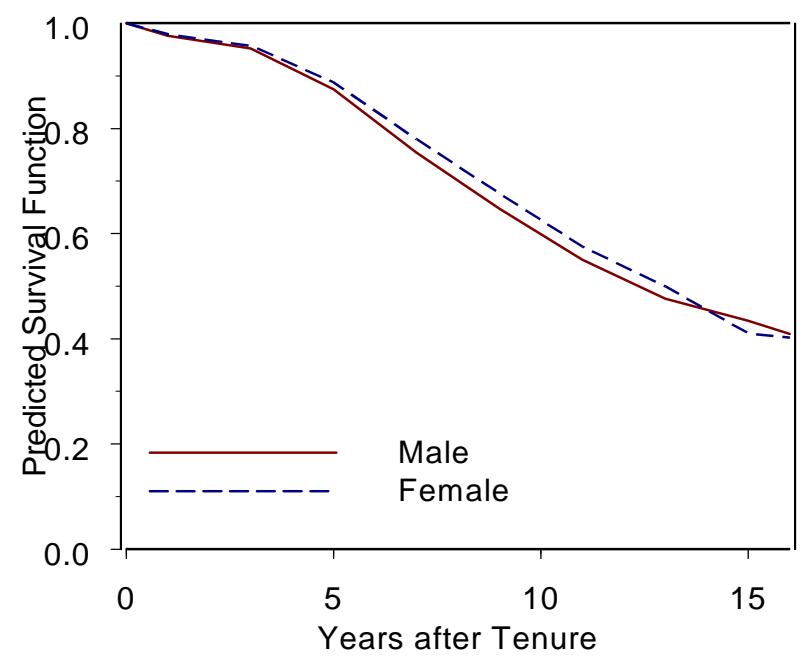

C. Physical Science

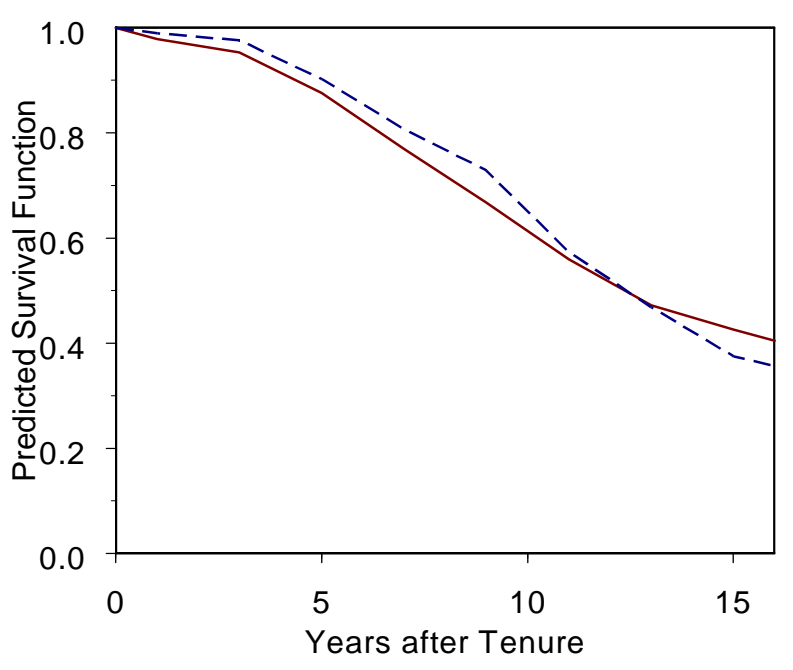

B. Life Science

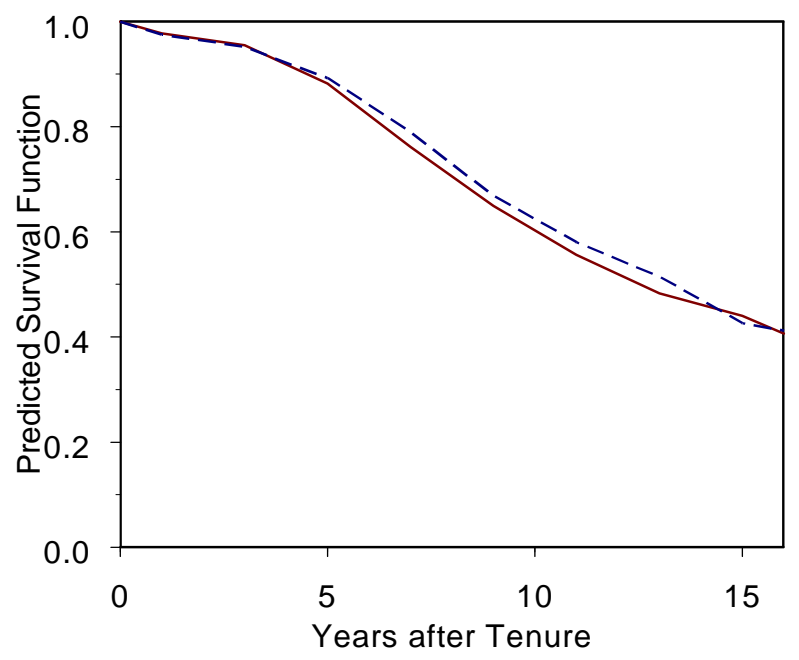

Source: 1973-2001 Survey of Doctorate Recipients 
Table A1: Probability of Having a Tenure Track Appointment within 5 Years of Ph.D.: 1973-2001 Survey of Doctorate Recipients

\begin{tabular}{|c|c|c|c|c|c|c|c|c|c|c|c|c|}
\hline \multirow[b]{2}{*}{ Variables: } & \multicolumn{3}{|c|}{ Science } & \multicolumn{3}{|c|}{ Life Science } & \multicolumn{3}{|c|}{ Physical Science } & \multicolumn{3}{|c|}{ Engineering } \\
\hline & Model 1 & Model 2 & Model 3 & Model 1 & Model 2 & Model 3 & Model 1 & Model 2 & Model 3 & Model 1 & Model 2 & Model 3 \\
\hline \multirow[t]{2}{*}{ Female } & -0.038 & -0.033 & 0.156 & -0.041 & -0.077 & 0.108 & -0.002 & -0.015 & 0.206 & 0.000 & 0.013 & 0.072 \\
\hline & $(0.009)$ & $(0.010)$ & $(0.018)$ & $(0.012)$ & $(0.013)$ & $(0.025)$ & $(0.016)$ & $(0.017)$ & $(0.029)$ & $(0.033)$ & $(0.035)$ & $(0.064)$ \\
\hline \multirow[t]{2}{*}{ Age at Ph.D. } & & 0.002 & 0.001 & & 0.003 & 0.002 & & -0.003 & -0.004 & & -0.008 & -0.010 \\
\hline & & $(0.001)$ & $(0.001)$ & & $(0.001)$ & $(0.001)$ & & $(0.002)$ & $(0.002)$ & & $(0.003)$ & $(0.003)$ \\
\hline \multirow[t]{2}{*}{ African American } & & 0.084 & 0.104 & & 0.102 & 0.117 & & 0.044 & $\underline{0.070}$ & & 0.081 & $\underline{0.103}$ \\
\hline & & $(0.021)$ & $(0.021)$ & & $(0.028)$ & (0.028) & & $(0.039)$ & $\overline{(0.038)}$ & & $(0.056)$ & $\overline{(0.054)}$ \\
\hline \multirow[t]{2}{*}{ Native American } & & 0.041 & 0.025 & & 0.091 & 0.072 & & 0.008 & -0.012 & & -0.103 & -0.129 \\
\hline & & $(0.068)$ & $(0.069)$ & & $(0.086)$ & $(0.088)$ & & $(0.160)$ & $(0.164)$ & & $(0.162)$ & $(0.165)$ \\
\hline \multirow[t]{2}{*}{ Asian } & & -0.113 & -0.111 & & -0.096 & -0.090 & & -0.089 & -0.088 & & -0.182 & -0.192 \\
\hline & & $(0.017)$ & $(0.017)$ & & $(0.025)$ & (0.025) & & $(0.028)$ & $(0.029)$ & & $(0.041)$ & $(0.042)$ \\
\hline \multirow[t]{2}{*}{ Other Race } & & -0.019 & 0.014 & & -0.001 & 0.022 & & -0.039 & 0.003 & & & \\
\hline & & $(0.093)$ & $(0.093)$ & & $(0.126)$ & $(0.126)$ & & (0.139) & (0.139) & & & \\
\hline \multirow[t]{2}{*}{ Foreign Born } & & -0.047 & -0.044 & & -0.087 & -0.086 & & -0.048 & -0.046 & & 0.032 & 0.044 \\
\hline & & $(0.015)$ & (0.015) & & $(0.022)$ & $(0.022)$ & & $(0.025)$ & $\overline{(0.025)}$ & & $(0.033)$ & $(0.033)$ \\
\hline \multirow[t]{2}{*}{ Year of Ph.D. } & & 0.000 & 0.000 & & -0.004 & -0.005 & & 0.005 & 0.005 & & 0.007 & 0.007 \\
\hline & & $(0.001)$ & $(0.001)$ & & $(0.001)$ & $(0.001)$ & & $(0.001)$ & $(0.001)$ & & $(0.002)$ & $(0.002)$ \\
\hline \multirow[t]{2}{*}{ Ph.D. from Research I } & & 0.052 & 0.052 & & 0.043 & $\underline{0.043}$ & & 0.112 & 0.122 & & 0.034 & 0.003 \\
\hline & & $(0.021)$ & $(0.021)$ & & $(0.024)$ & $(0.024)$ & & $(0.054)$ & $(0.054)$ & & $(0.076)$ & $(0.077)$ \\
\hline \multirow[t]{2}{*}{ Ph.D. from Research II } & & 0.062 & 0.054 & & 0.023 & 0.018 & & 0.155 & 0.156 & & 0.085 & 0.048 \\
\hline & & $(0.023)$ & $(0.023)$ & & $(0.029)$ & $(0.029)$ & & $(0.050)$ & $(0.050)$ & & $(0.074)$ & $(0.081)$ \\
\hline \multirow[t]{2}{*}{ Ph.D. from Doctorate I } & & 0.100 & 0.099 & & 0.095 & 0.099 & & 0.199 & 0.198 & & -0.092 & -0.119 \\
\hline & & $(0.026)$ & $(0.026)$ & & $(0.036)$ & $(0.036)$ & & $(0.048)$ & (0.048) & & $(0.099)$ & $(0.103)$ \\
\hline \multirow[t]{2}{*}{ Ph.D. from Doctorate II } & & 0.066 & 0.062 & & 0.022 & 0.026 & & 0.197 & 0.200 & & 0.018 & -0.025 \\
\hline & & $(0.031)$ & $(0.031)$ & & $(0.043)$ & $(0.043)$ & & $(0.051)$ & $(0.051)$ & & $(0.097)$ & $(0.105)$ \\
\hline \multirow[t]{2}{*}{ Married } & & & 0.218 & & & 0.220 & & & 0.222 & & & 0.221 \\
\hline & & & (0.016) & & & $(0.023)$ & & & $(0.026)$ & & & $(0.045)$ \\
\hline \multirow[t]{2}{*}{ Total Children } & & & 0.029 & & & 0.036 & & & $\underline{0.021}$ & & & $\underline{0.025}$ \\
\hline & & & $(0.007)$ & & & $(0.010)$ & & & $\overline{(0.012)}$ & & & $(\overline{0.014)}$ \\
\hline \multirow[t]{2}{*}{ Children $<6=1$} & & & -0.022 & & & -0.026 & & & -0.001 & & & -0.069 \\
\hline & & & $(0.016)$ & & & $(0.023)$ & & & $(0.029)$ & & & $(0.037)$ \\
\hline
\end{tabular}


Table A1: Probability of Having a Tenure Track Appointment within 5 Years of Ph.D.: 1973-2001 Survey of Doctorate Recipients (continued)

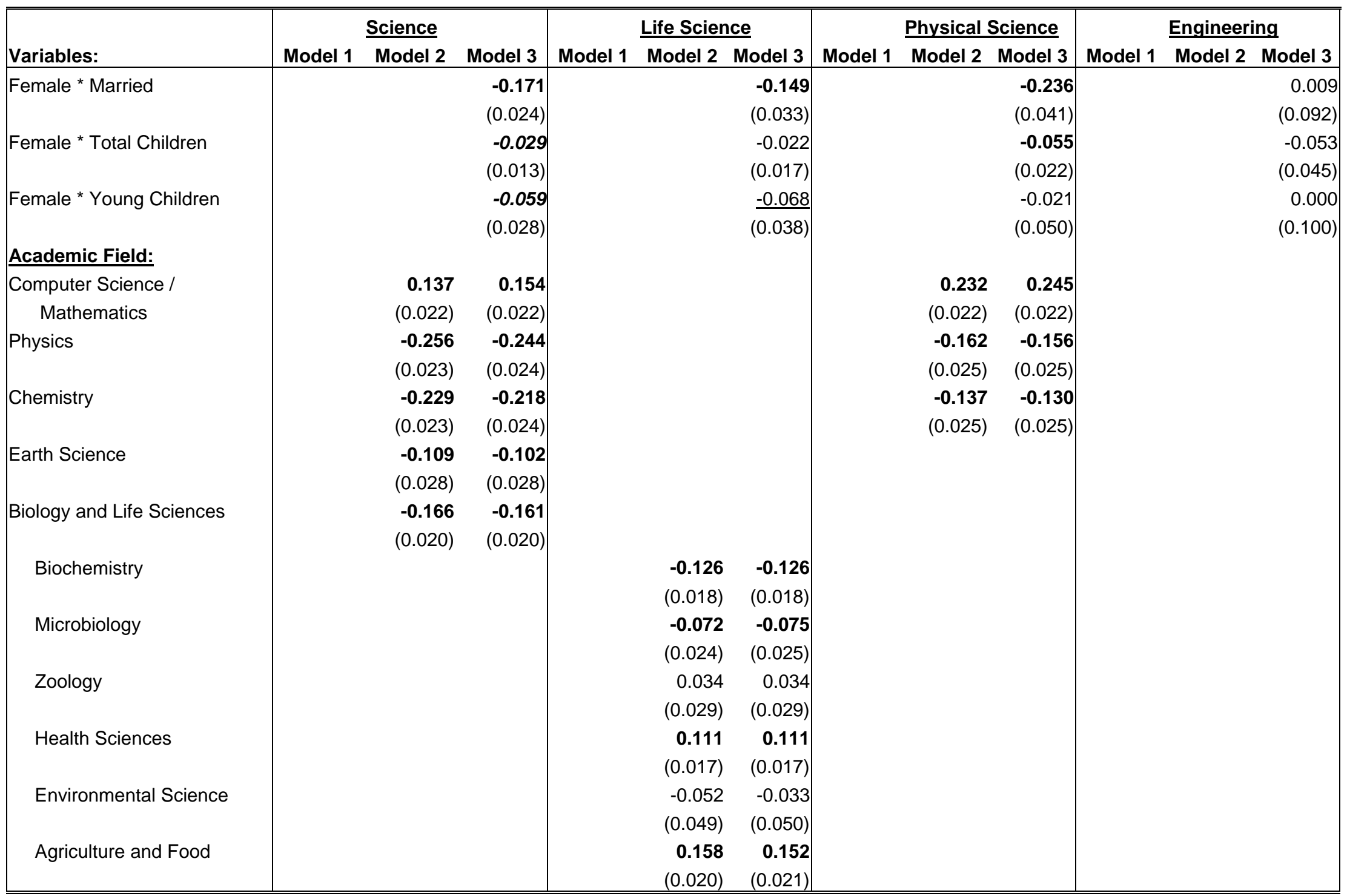


Table A1: Probability of Having a Tenure Track Appointment within 5 Years of Ph.D.: 1973-2001 Survey of Doctorate Recipients (continued)

\begin{tabular}{|c|c|c|c|c|c|c|c|c|c|c|c|c|}
\hline \multirow[b]{2}{*}{ Academic Field: } & \multicolumn{3}{|c|}{ Science } & \multicolumn{3}{|c|}{ Life Science } & \multicolumn{3}{|c|}{ Physical Science } & \multicolumn{3}{|c|}{ Engineering } \\
\hline & Model 1 & Model 2 & Model 3 & Model 1 & Model 2 & Model 3 & Model 1 & Model 2 & Model 3 & Model 1 & Model 2 & Model 3 \\
\hline Engineering & & $\begin{array}{r}-0.007 \\
(0.024)\end{array}$ & $\begin{array}{r}-0.005 \\
(0.024)\end{array}$ & & & & & & & & & \\
\hline Aerospace & & & & & & & & & & & $\begin{array}{r}0.092 \\
(0.059)\end{array}$ & $\begin{array}{r}0.092 \\
(0.059)\end{array}$ \\
\hline Chemical & & & & & & & & & & & $\begin{array}{r}0.055 \\
(0.042)\end{array}$ & $\begin{array}{r}0.067 \\
(0.041)\end{array}$ \\
\hline Civil & & & & & & & & & & & $\begin{array}{r}0.157 \\
(0.033)\end{array}$ & $\begin{array}{r}0.160 \\
(0.033)\end{array}$ \\
\hline Electrical & & & & & & & & & & & $\begin{array}{r}0.091 \\
(0.029)\end{array}$ & $\begin{array}{r}0.100 \\
(0.029)\end{array}$ \\
\hline Mechanical & & & & & & & & & & & $\begin{array}{r}0.135 \\
(0.033)\end{array}$ & $\begin{array}{r}0.148 \\
(0.033)\end{array}$ \\
\hline Industrial & & & & & & & & & & & $\begin{array}{r}0.273 \\
(0.030)\end{array}$ & $\begin{array}{r}0.277 \\
(0.028)\end{array}$ \\
\hline Observations & 12745 & 12745 & 12745 & 6826 & 6826 & 6826 & 4365 & 4365 & 4365 & 1554 & 1554 & 1554 \\
\hline Likelihood Ratio Stat & 17.42 & 820.28 & 1156.36 & 10.93 & 368.44 & 545.49 & 0.01 & 555.55 & 691.06 & 0.00 & 102.37 & 147.38 \\
\hline
\end{tabular}

Notes: Coefficients report change in probability. Standard Errors in Parentheses. Bold 1\%; Bold Italics 5\%. Underline 10\%. 
Table A2: Probit Estimates of the Probability of Tenure within 11 Years of Ph.D. by Field, 1973-2001 Survey of Doctorate Recipients

\begin{tabular}{|c|c|c|c|c|}
\hline & Science & Life Science & $\begin{array}{l}\text { Physical } \\
\text { Science }\end{array}$ & Engineering \\
\hline \multirow[t]{2}{*}{ Female } & 0.003 & -0.032 & 0.010 & 0.017 \\
\hline & $(0.017)$ & $(0.024)$ & $(0.029)$ & $(0.052)$ \\
\hline \multirow[t]{2}{*}{ Age at Ph.D. } & 0.008 & 0.008 & 0.001 & -0.002 \\
\hline & $(0.002)$ & $(0.003)$ & $(0.003)$ & $(0.005)$ \\
\hline \multirow[t]{2}{*}{ African American } & -0.048 & -0.037 & -0.048 & -0.066 \\
\hline & $(0.035)$ & $(0.050)$ & $(0.061)$ & $(0.083)$ \\
\hline \multirow[t]{2}{*}{ Native American } & -0.057 & 0.036 & 0.070 & -0.498 \\
\hline & $(0.103)$ & $(0.134)$ & $(0.246)$ & $(0.195)$ \\
\hline \multirow[t]{2}{*}{ Asian } & 0.001 & -0.004 & 0.028 & 0.043 \\
\hline & $(0.030)$ & $(0.047)$ & $(0.047)$ & $(0.061)$ \\
\hline \multirow[t]{2}{*}{ Other Race } & 0.250 & & 0.143 & \\
\hline & $(0.143)$ & & $(0.215)$ & \\
\hline \multirow[t]{2}{*}{ Foreign Born } & -0.062 & -0.120 & -0.060 & -0.016 \\
\hline & $(0.025)$ & $(0.039)$ & $(0.042)$ & $(0.050)$ \\
\hline \multirow[t]{2}{*}{ Year of Ph.D. } & -0.008 & -0.017 & 0.001 & 0.005 \\
\hline & $(0.002)$ & $(0.003)$ & $(0.003)$ & $(0.005)$ \\
\hline \multirow[t]{2}{*}{ Ph.D. from Research I } & 0.054 & 0.060 & -0.015 & 0.029 \\
\hline & $(0.039)$ & $(0.044)$ & $(0.096)$ & $(0.136)$ \\
\hline \multirow[t]{2}{*}{ Ph.D. from Research II } & 0.038 & 0.050 & -0.023 & 0.023 \\
\hline & $(0.043)$ & $(0.055)$ & $(0.105)$ & $(0.137)$ \\
\hline \multirow[t]{2}{*}{ Ph.D. from Doctorate I } & 0.058 & 0.134 & -0.044 & 0.039 \\
\hline & $(0.049)$ & $(0.066)$ & $(0.111)$ & $(0.148)$ \\
\hline \multirow[t]{2}{*}{ Ph.D. from Doctorate II } & 0.077 & 0.122 & 0.030 & -0.020 \\
\hline & 0.056 & 0.079 & 0.115 & 0.185 \\
\hline \multicolumn{5}{|l|}{11 Years After Ph.D.: } \\
\hline \multirow{2}{*}{ Married } & 0.046 & 0.033 & $\underline{0.067}$ & 0.124 \\
\hline & $(0.021)$ & $(0.029)$ & $(0.036)$ & $(0.065)$ \\
\hline \multirow[t]{2}{*}{ Total Children } & 0.015 & 0.023 & 0.005 & 0.005 \\
\hline & $(0.008)$ & $(0.012)$ & $(0.015)$ & $(0.019)$ \\
\hline \multirow[t]{2}{*}{ Children $<6$} & -0.028 & -0.039 & -0.009 & -0.016 \\
\hline & $(0.020)$ & $(0.028)$ & $(0.036)$ & $(0.047)$ \\
\hline \multirow[t]{2}{*}{ Cumulative Employers } & -0.161 & -0.137 & -0.211 & -0.140 \\
\hline & $(0.009)$ & $(0.012)$ & $(0.016)$ & $(0.025)$ \\
\hline \multirow[t]{2}{*}{ Private University } & -0.108 & -0.155 & -0.068 & -0.045 \\
\hline & $(0.017)$ & $(0.024)$ & $(0.029)$ & $(0.046)$ \\
\hline \multirow[t]{2}{*}{ Research I } & 0.044 & $\underline{0.044}$ & -0.002 & 0.057 \\
\hline & $(0.018)$ & $(0.025)$ & $(0.035)$ & $(0.045)$ \\
\hline \multirow[t]{2}{*}{ Liberal Arts I } & 0.097 & 0.105 & 0.121 & 0.011 \\
\hline & $(0.021)$ & $(0.033)$ & $(0.032)$ & $(0.058)$ \\
\hline \multirow[t]{2}{*}{ Medical School } & -0.100 & -0.095 & -0.047 & -0.121 \\
\hline & $(0.020)$ & $(0.024)$ & $(0.047)$ & $(0.063)$ \\
\hline \multirow[t]{2}{*}{ Primary Work Research } & 0.090 & 0.137 & 0.087 & 0.094 \\
\hline & $(0.035)$ & $(0.044)$ & $(0.076)$ & $(0.105)$ \\
\hline \multirow[t]{2}{*}{ Primary Work Teach } & 0.435 & 0.442 & 0.498 & 0.406 \\
\hline & $(0.030)$ & $(0.037)$ & $(0.065)$ & $(0.100)$ \\
\hline Primary Work Manage & 0.210 & 0.213 & 0.214 & 0.146 \\
\hline & $(0.035)$ & $(0.049)$ & $(0.064)$ & $(0.089)$ \\
\hline
\end{tabular}


Table A2: Probit Estimates of the Probability of Tenure within 11 Years of Ph.D. by Field, 1973-2001 Survey of Doctorate Recipients (continued)

\begin{tabular}{|c|c|c|c|c|}
\hline & Science & Life Science & $\begin{array}{c}\text { Physical } \\
\text { Science }\end{array}$ & Engineering \\
\hline \multicolumn{5}{|l|}{11 Years After Ph.D.: } \\
\hline Secondary Work Research & $\begin{array}{c}0.011 \\
(0.030)\end{array}$ & $\begin{array}{l}-0.045 \\
(0.046)\end{array}$ & $\begin{array}{c}0.026 \\
(0.045)\end{array}$ & $\begin{array}{c}0.081 \\
(0.077)\end{array}$ \\
\hline Secondary Work Teach & $\begin{array}{c}\mathbf{0 . 2 6 0} \\
(0.029)\end{array}$ & $\begin{array}{c}\mathbf{0 . 1 3 8} \\
(0.047)\end{array}$ & $\begin{array}{c}\mathbf{0 . 3 8 8} \\
(0.036)\end{array}$ & $\begin{array}{c}\mathbf{0 . 2 2 1} \\
(0.063)\end{array}$ \\
\hline Secondary Work Manage & $\begin{array}{c}0.077 \\
(0.034)\end{array}$ & $\begin{array}{l}-0.021 \\
(0.051)\end{array}$ & $\begin{array}{c}0.145 \\
(0.048)\end{array}$ & $\begin{array}{c}0.193 \\
(0.061)\end{array}$ \\
\hline Secondary Work Other & $\begin{array}{l}-0.071 \\
(0.036)\end{array}$ & $\begin{array}{l}-0.147 \\
(0.048)\end{array}$ & $\begin{array}{l}-0.038 \\
(0.060)\end{array}$ & $\begin{array}{c}0.064 \\
(0.088)\end{array}$ \\
\hline $\begin{array}{l}\text { Government Support } \\
\text { in Current Year }\end{array}$ & $\begin{array}{c}0.003 \\
(0.022)\end{array}$ & $\begin{array}{l}0.007 \\
(0.031)\end{array}$ & $\begin{array}{c}0.023 \\
(0.040)\end{array}$ & $\begin{array}{l}-0.075 \\
(0.052)\end{array}$ \\
\hline $\begin{array}{l}\text { Cumulative Years of } \\
\text { Government Support }\end{array}$ & $\begin{array}{c}0.004 \\
(0.006)\end{array}$ & $\begin{array}{l}0.006 \\
(0.009)\end{array}$ & $\begin{array}{l}-0.002 \\
(0.012)\end{array}$ & $\begin{array}{c}0.048 \\
(0.016)\end{array}$ \\
\hline Cumulative Papers & $\begin{array}{c}\mathbf{0 . 0 0 2} \\
(0.001)\end{array}$ & $\begin{array}{c}0.001 \\
(0.001)\end{array}$ & $\begin{array}{c}0.001 \\
(0.001)\end{array}$ & $\begin{array}{c}0.005 \\
(0.002)\end{array}$ \\
\hline Cumulative Publications & $\begin{array}{l}\mathbf{0 . 0 0 7} \\
(0.001)\end{array}$ & $\begin{array}{c}\mathbf{0 . 0 0 9} \\
(0.001)\end{array}$ & $\begin{array}{l}\mathbf{0 . 0 0 6} \\
(0.002)\end{array}$ & $\begin{array}{l}-0.002 \\
(0.002)\end{array}$ \\
\hline Academic Fields: & & & & \\
\hline $\begin{array}{l}\text { Computer Science / } \\
\text { Mathematics }\end{array}$ & $\begin{array}{l}-0.010 \\
(0.039)\end{array}$ & & $\begin{array}{c}\mathbf{0 . 0 8 5} \\
(0.041)\end{array}$ & \\
\hline Physics & $\begin{array}{l}-0.235 \\
(0.041)\end{array}$ & & $\begin{array}{l}-0.146 \\
(0.047)\end{array}$ & \\
\hline Chemistry & $\begin{array}{l}-0.198 \\
(0.041)\end{array}$ & & $\begin{array}{l}-0.125 \\
(0.046)\end{array}$ & \\
\hline Earth Science & $\begin{array}{l}-0.104 \\
(0.047)\end{array}$ & & & \\
\hline Biology and Life Sciences & $\begin{array}{l}-0.215 \\
(0.033)\end{array}$ & & & \\
\hline Biochemistry & & $\begin{array}{l}-0.100 \\
(0.033)\end{array}$ & & \\
\hline Microbiology & & $\frac{-0.079}{(0.043)}$ & & \\
\hline Zoology & & $\begin{array}{c}\mathbf{0 . 1 2 4} \\
(0.047)\end{array}$ & & \\
\hline Health Sciences & & $\begin{array}{c}0.142 \\
(0.030)\end{array}$ & & \\
\hline Environmental Science & & $\begin{array}{c}0.162 \\
(0.080)\end{array}$ & & \\
\hline Agriculture and Food & & $\begin{array}{l}\mathbf{0 . 2 1 6} \\
(0.035)\end{array}$ & & \\
\hline Engineering & $\begin{array}{l}-0.047 \\
(0.039)\end{array}$ & & & \\
\hline
\end{tabular}


Table A2: Probit Estimates of the Probability of Tenure within 11 Years of Ph.D. by Field, 1973-2001 Survey of Doctorate Recipients (continued)

\begin{tabular}{|c|c|c|c|c|}
\hline & Science & Life Science & $\begin{array}{l}\text { Physical } \\
\text { Science }\end{array}$ & Engineering \\
\hline \multicolumn{5}{|l|}{ Academic Fields: } \\
\hline \multicolumn{5}{|l|}{ Engineering } \\
\hline Aerospace & & & & $\begin{array}{l}-0.059 \\
(0.109)\end{array}$ \\
\hline Chemical & & & & $\begin{array}{c}0.017 \\
(0.076)\end{array}$ \\
\hline Civil & & & & $\begin{array}{c}0.009 \\
(0.063)\end{array}$ \\
\hline Electrical & & & & $\begin{array}{c}0.002 \\
(0.052)\end{array}$ \\
\hline Mechanical & & & & $\begin{array}{c}0.013 \\
(0.065)\end{array}$ \\
\hline Industrial & & & & $\begin{array}{l}-0.043 \\
(0.100)\end{array}$ \\
\hline Observations & 5,187 & 2,756 & 1,757 & 669 \\
\hline Likelihood Ratio Stat & $1,393.41$ & 768.98 & 570.18 & 145.83 \\
\hline
\end{tabular}

Notes: Coefficients report change in probability. Standard Errors in Parentheses. Bold 1\%; Bold Italics 5\%. Underline 10\%. 
Table A3: Probit Estimates of the Probability of Full Professor within 15 Years of Ph.D. by Field, 1973-2001 Survey of Doctorate Recipients

\begin{tabular}{|c|c|c|c|c|}
\hline & Science & Life Science & $\begin{array}{l}\text { Physical } \\
\text { Science }\end{array}$ & Engineering \\
\hline \multirow[t]{2}{*}{ Female } & -0.048 & -0.085 & -0.024 & 0.088 \\
\hline & $(0.021)$ & $(0.028)$ & $(0.037)$ & $(0.097)$ \\
\hline \multirow[t]{2}{*}{ Age at Ph.D. } & 0.004 & 0.002 & 0.004 & 0.011 \\
\hline & $(0.002)$ & $(0.003)$ & $(0.004)$ & $(0.008)$ \\
\hline \multirow[t]{2}{*}{ African American } & -0.102 & -0.058 & $\underline{-0.132}$ & $\underline{-0.224}$ \\
\hline & $(0.040)$ & $(0.057)$ & $(0.069)$ & $(0.127)$ \\
\hline \multirow[t]{2}{*}{ Native American } & -0.091 & -0.216 & -0.129 & 0.221 \\
\hline & $(0.138)$ & $(0.161)$ & $(0.229)$ & $(0.275)$ \\
\hline \multirow[t]{2}{*}{ Asian } & 0.028 & -0.023 & 0.122 & 0.001 \\
\hline & $(0.038)$ & $(0.055)$ & $(0.063)$ & $(0.106)$ \\
\hline \multirow[t]{2}{*}{ Other Race } & 0.367 & & & \\
\hline & $(0.217)$ & & & \\
\hline \multirow[t]{2}{*}{ Foreign Born } & 0.036 & -0.022 & 0.050 & 0.114 \\
\hline & $(0.032)$ & $(0.049)$ & $(0.053)$ & $(0.083)$ \\
\hline \multirow[t]{2}{*}{ Year of Ph.D. } & -0.016 & -0.016 & -0.014 & -0.030 \\
\hline & $(0.003)$ & $(0.004)$ & $(0.004)$ & $(0.009)$ \\
\hline \multirow[t]{2}{*}{ Ph.D. from Research I } & 0.049 & 0.062 & 0.127 & -0.175 \\
\hline & $(0.048)$ & $(0.050)$ & $(0.153)$ & $(0.245)$ \\
\hline \multirow[t]{2}{*}{ Ph.D. from Research II } & 0.034 & 0.076 & 0.071 & -0.081 \\
\hline & $(0.056)$ & $(0.065)$ & $(0.172)$ & $(0.281)$ \\
\hline \multirow[t]{2}{*}{ Ph.D. from Doctorate I } & 0.097 & 0.158 & 0.215 & -0.528 \\
\hline & $(0.065)$ & $(0.084)$ & $(0.172)$ & $(0.071)$ \\
\hline \multirow[t]{2}{*}{ Ph.D. from Doctorate II } & 0.075 & 0.105 & 0.197 & -0.322 \\
\hline & $(0.070)$ & $(0.090)$ & $(0.180)$ & $(0.240)$ \\
\hline \multicolumn{5}{|l|}{15 Years After Ph.D.: } \\
\hline \multirow[t]{2}{*}{ Married } & 0.014 & -0.005 & 0.074 & -0.061 \\
\hline & $(0.024)$ & $(0.033)$ & $(0.040)$ & $(0.097)$ \\
\hline \multirow[t]{2}{*}{ Total Children } & 0.009 & 0.013 & -0.020 & 0.061 \\
\hline & $(0.009)$ & $(0.013)$ & $(0.016)$ & $(0.032)$ \\
\hline \multirow[t]{2}{*}{ Children $<6=1$} & -0.029 & -0.039 & 0.001 & -0.065 \\
\hline & $(0.024)$ & $(0.033)$ & $(0.041)$ & $(0.083)$ \\
\hline \multirow[t]{2}{*}{ Cumulative Employers } & -0.044 & -0.034 & -0.069 & $\underline{-0.061}$ \\
\hline & $(0.009)$ & $(0.011)$ & $(0.017)$ & $(0.037)$ \\
\hline \multirow[t]{2}{*}{ Private University } & -0.050 & $\underline{-0.055}$ & -0.047 & 0.045 \\
\hline & $(0.021)$ & $(0.030)$ & $(0.034)$ & $(0.070)$ \\
\hline \multirow[t]{2}{*}{ Research I } & -0.003 & -0.024 & -0.005 & 0.039 \\
\hline & $(0.022)$ & $(0.029)$ & $(0.043)$ & $(0.074)$ \\
\hline \multirow[t]{2}{*}{ Liberal Arts I } & 0.108 & 0.099 & 0.150 & 0.044 \\
\hline & $(0.025)$ & $(0.038)$ & $(0.038)$ & $(0.092)$ \\
\hline \multirow[t]{2}{*}{ Medical School } & -0.107 & -0.085 & $\underline{-0.096}$ & -0.056 \\
\hline & $(0.024)$ & $(0.029)$ & $(0.056)$ & $(0.100)$ \\
\hline \multirow[t]{2}{*}{ Primary Work Research } & 0.055 & 0.042 & 0.109 & 0.379 \\
\hline & $(0.050)$ & $(0.058)$ & $(0.116)$ & $(0.168)$ \\
\hline \multirow[t]{2}{*}{ Primary Work Teach } & 0.161 & 0.135 & 0.276 & $\underline{0.361}$ \\
\hline & $(0.049)$ & $(0.060)$ & $(0.101)$ & $(0.190)$ \\
\hline Primary Work Manage & 0.231 & 0.203 & 0.291 & $\underline{0.326}$ \\
\hline & $(0.054)$ & $(0.067)$ & $(0.115)$ & $(0.153)$ \\
\hline
\end{tabular}


Table A3: Probit Estimates of the Probability of Full Professor within 15 Years of Ph.D. by Field, 1973-2001 Survey of Doctorate Recipients (continued)

\begin{tabular}{|c|c|c|c|c|}
\hline & Science & Life Science & $\begin{array}{l}\text { Physical } \\
\text { Science }\end{array}$ & Engineering \\
\hline \multirow[t]{2}{*}{ Secondary Work Research } & 0.002 & -0.063 & -0.019 & 0.111 \\
\hline & $(0.042)$ & $(0.066)$ & $(0.058)$ & $(0.164)$ \\
\hline \multirow[t]{2}{*}{ Secondary Work Teach } & 0.136 & 0.026 & 0.264 & 0.179 \\
\hline & $(0.046)$ & $(0.071)$ & $(0.072)$ & $(0.170)$ \\
\hline \multirow[t]{2}{*}{ Secondary Work Manage } & 0.101 & 0.024 & 0.106 & 0.255 \\
\hline & $(0.047)$ & $(0.073)$ & $(0.069)$ & $(0.148)$ \\
\hline \multirow[t]{2}{*}{ Secondary Work Other } & 0.046 & -0.002 & 0.015 & 0.042 \\
\hline & $(0.051)$ & $(0.075)$ & $(0.079)$ & $(0.197)$ \\
\hline \multirow{2}{*}{$\begin{array}{l}\text { Government Support } \\
\text { in Current Year }\end{array}$} & 0.010 & 0.004 & 0.048 & -0.056 \\
\hline & $(0.026)$ & $(0.034)$ & $(0.045)$ & $(0.087)$ \\
\hline \multirow{2}{*}{$\begin{array}{l}\text { Cumulative Years of } \\
\text { Government Support }\end{array}$} & 0.012 & 0.007 & 0.031 & 0.015 \\
\hline & $(0.006)$ & $(0.007)$ & $(0.010)$ & $(0.019)$ \\
\hline \multirow[t]{2}{*}{ Cumulative Papers } & 0.002 & 0.000 & 0.002 & 0.005 \\
\hline & $(0.001)$ & $(0.001)$ & $(0.002)$ & $(0.003)$ \\
\hline \multirow[t]{2}{*}{ Cumulative Publications } & 0.008 & 0.009 & 0.008 & 0.004 \\
\hline & $(0.001)$ & $(0.001)$ & $(0.002)$ & $(0.003)$ \\
\hline \multicolumn{5}{|l|}{ Academic Field: } \\
\hline \multirow{2}{*}{$\begin{array}{c}\text { Computer Science / } \\
\text { Mathematics }\end{array}$} & -0.045 & & 0.046 & \\
\hline & $(0.040)$ & & $(0.046)$ & \\
\hline \multirow[t]{2}{*}{ Physics } & -0.115 & & -0.073 & \\
\hline & $(0.045)$ & & $(0.052)$ & \\
\hline \multirow[t]{2}{*}{ Chemistry } & -0.139 & & -0.083 & \\
\hline & $(0.041)$ & & $(0.050)$ & \\
\hline \multirow[t]{2}{*}{ Earth Science } & -0.060 & & & \\
\hline & $(0.047)$ & & & \\
\hline \multirow[t]{2}{*}{ Biology and Life Sciences } & -0.125 & & & \\
\hline & $(0.036)$ & & & \\
\hline \multirow[t]{2}{*}{ Biochemistry } & & -0.081 & & \\
\hline & & $(0.039)$ & & \\
\hline \multirow[t]{2}{*}{ Microbiology } & & 0.005 & & \\
\hline & & $(0.051)$ & & \\
\hline \multirow[t]{2}{*}{ Zoology } & & 0.121 & & \\
\hline & & $(0.051)$ & & \\
\hline \multirow[t]{2}{*}{ Health Sciences } & & 0.105 & & \\
\hline & & $(0.038)$ & & \\
\hline \multirow{2}{*}{\multicolumn{2}{|c|}{ Environmental Science }} & 0.044 & & \\
\hline & & $(0.091)$ & & \\
\hline \multirow[t]{2}{*}{ Agriculture and Food } & & 0.156 & & \\
\hline & & $(0.042)$ & & \\
\hline \multirow[t]{2}{*}{ Engineering } & 0.022 & & & \\
\hline & $(0.045)$ & & & \\
\hline
\end{tabular}


Table A3: Probit Estimates of the Probability of Full Professor within 15 Years of Ph.D. by Field, 1973-2001 Survey of Doctorate Recipients (continued)

\begin{tabular}{|c|c|c|c|c|}
\hline & Science & Life Science & $\begin{array}{l}\text { Physical } \\
\text { Science }\end{array}$ & Engineering \\
\hline \multicolumn{5}{|l|}{ Academic Field: } \\
\hline \multicolumn{5}{|l|}{ Engineering } \\
\hline Aerospace & & & & $\begin{array}{l}-0.112 \\
(0.180)\end{array}$ \\
\hline Chemical & & & & $\begin{array}{l}-0.129 \\
(0.127)\end{array}$ \\
\hline Civil & & & & $\begin{array}{l}-0.028 \\
(0.097)\end{array}$ \\
\hline Electrical & & & & $\begin{array}{l}-0.029 \\
(0.082)\end{array}$ \\
\hline Mechanical & & & & $\frac{-0.181}{(0.103)}$ \\
\hline Industrial & & & & $\begin{array}{l}-0.001 \\
(0.169)\end{array}$ \\
\hline Observations & 3,223 & 1,728 & 1,161 & 330 \\
\hline Likelihood Ratio Stat & 355.72 & 187.11 & 187.23 & 66.27 \\
\hline
\end{tabular}

Notes: Coefficients report chnge in probability. Standard Errors in Parentheses. Bold 1\%; Bold Italics 5\%. 